\title{
Poetyka, \\ genetyka, praca. \\ (O sztuce rymotwórczej)
}

\section{Mateusz Antoniuk}

\author{
ORCID: 0000-0002-1608-2691
}

\section{Wstępne pytania, próbne odpowiedzi}

Do czego poetyce przydać się może - krytyka genetyczna? Oczywiście, pytanie to da się odwrócić: dlaczego krytyka genetyczna szuka kontaktu z poetyką? Bo niewątpliwie szuka go (i znajduje) od kilku dekad, co unaocznia między innymi jeden z klasycznych „elementarzy” critique génétique, czyli Genetyka tekstów Pierre'a-Marca de Biasiego ${ }^{1}$. Ale tak ustawione pytanie - po co poetyka genetyce? - wydaje mi się jednak i mniej stosowne, i mniej ciekawe. Po pierwsze dlatego, że zabieram głos na „forum poetyki”, istotniejsza wydaje się więc perspektywa gospodarza, czyli kwestia korzyści, jakie poetyka wynieść może z kooperacji z genetyką (a nie odwrotnie). Po drugie z tej przyczyny, że odpowiedź na pytanie o zasługi poetyki dla genetyki wydaje mi się względnie trywialna: przedmiot zainteresowania krytyków genetycznych ma liczne właściwości, które trudno zrozumieć (które nawet trudno zauważyć) bez pojęciowego instrumentarium tzw. poetyki opisowej. Przedmiot ów można określać rozmaicie: mianem tekstu in statu nascendi, mianem brulionu, który, jak przekonuje część badaczy

\footnotetext{
${ }^{1}$ Por. Pierre-Marc de Biasi, Genetyka tekstów, tłum. Filip Kwiatek, Maria Prussak (Warszawa: Wydawnictwo IBL, 2015), 142: „Pytania o związki między interpretacją tekstu i krytyką genetyczną okazały się najbardziej owocne - zarówno z teoretycznego punktu widzenia, jak i przy okazji pierwszych poważnych studiów nad zespołami dokumentów w badaniach prowadzonych przez narratologów i specjalistów od poetyki”. Poetyka wymieniania jest w podręczniku de Biasiego jako pierwszy (z dziewięciu) modus literaturoznawstwa, z którym współpracuje krytyka genetyczna.
} 
genezy, tekstem jeszcze nie jest ${ }^{2}$, czy wreszcie mianem procesu tekstotwórczego (bądź jego śladu, resztki, zapisu). Do jakiejkolwiek uciekniemy się formuły, „to”, czym zajmuje się krytyka genetyczna, będzie zawsze wykazywało właściwości formalne, którymi profesjonalnie zajmuje się tak zwana poetyka. A zatem: pierwszy, brulionowy zarys wiersza (nawet jeśli jeszcze niedokończony, przerwany) będzie już miał jakąś delimitację wersową, jakieś parametry brzmieniowo-rytmiczne; genetyk chcący je nazwać będzie musiał sięgnąć do słownika wersologów³. Opowiadanie w swej wersji wczesnej, rękopisowej i roboczej, pełnej jeszcze skreśleń, będzie już miało jakąś narrację, być może radykalnie inną od narracji „zafiksowanej” w dziele finalnym - bez znajomości słownika narratologii badacz może nawet nie zauważyć istotnego wymiaru tekstoprzetwórczej dynamiki (nie od dziś wiadomo, że skłonni jesteśmy nie dostrzegać tego, czego nie umiemy nazwać) ${ }^{4}$. Krytyk genetyczny zajmujący się historią powstawania utworu dramatycznego może potrzebować pojęciowo-analitycznego instrumentarium poetyki dramatu, by umiejętnie scharakteryzować przemiany, jakim ulegał tekst sztuki, nim zastygł w postaci znanej z publikacji5. Serię przykładów łatwo byłoby kontynuować, przerywam ją jednak, bo niepostrzeżenie odpowiedź na „mniej ciekawe” pytanie, miast być dwuzdaniową dygresją, rozrasta się do rozmiarów dużego akapitu. Reasumując: poetyka jest dla genetyki jednym z najważniejszych języków, warunkujących, z jednej strony, jej doświadczenie rzeczywistości (tej rzeczywistości, którą ona chce poznawać), z drugiej zaś, jej zdolności komunikowania owego doświadczenia ${ }^{6}$.

2 Zastrzeżenia pod adresem odnoszenia pojęcia „tekstu” do brulionu, czyli roboczego autografu pisarza, podnoszone są dość często przez krytykę genetyczną. Jeden z jej wybitnych przedstawicieli, Daniel Ferrer, powiada (w kontekście konkretnego brulionu Joyce'a, lecz stwierdzenie to, jak się zdaje, ma charakter zamierzonej ekstrapolacji): „brulion nie jest ani tekstem, ani dyskursem; jest protokołem tworzenia tekstu. Można go porównać do partytury muzycznej, która nie jest melodyjna ani nawet dźwięczna, lecz tworzy muzykę; albo do nazw koloru, zanotowanych przez malarza na pospiesznym szkicu ołówkowym, które same w sobie nie są elementami pikturalnymi (chociaż mogą nabywać wtórnej pikturalności, na przykład w malarstwie Jaspera Johnsa), ale stanowią instrukcję wykonania przyszłego obrazu”. Tłum. Mateusz Antoniuk. Daniel Ferrer, „The Open Space of the Draft Page: James Joyce and Modern Manuscripts”, w The Iconic Page in Manuscript, Print, and Digital Culture, red. George Bornstein i Theresa Tinkle (Ann Arbor: University of Michigan Press, 1998), 261. Oczywiście, kwestia, „czy brulion można czy nie można określać zasadnie mianem tekstu”, prowadzi, koniec końców, do esencjalnego (i przepastnego) pytania: „co to jest tekst?”.

${ }^{3}$ Przykładowo Curtis Bradford przyglądał się metrotwórczym działaniom Yeatsa, który kształtując w brulionach trzecią część poematu The Tower (Wieża), wahał się między konstrukcją wersu z trzema albo czterema akcentami. Zob. Curtis Bradford, Yeats at Work (New York: Ecco Press, 1978), 11-12.

${ }^{4}$ Wzorcowym przykładem mariażu genetyki z narratologią pozostaje książka Raymonde’a Debraya Genette’a Métamorphoses du récit (Paris: Seuil, 1988). Na gruncie polskim przykładem genetycznego studium, analizującego bardzo ciekawą przemianę narracyjnej formy powieści w toku jej brulionowego powstawania, jest szkic Zofii Mitosek, niewątpliwej pionierki polskiej krytyki genetycznej, poświęcony Bramom raju badaczka odsłania tu między innymi mechanizm przejścia od modelu klasycznej narracji trzecioosobowej do eksperymentalnej „narracji mieszanej”, polifonicznej i wielogłosowej, diagnozując równocześnie światopoglądowe konsekwencje tego przesunięcia. Swoją metodę analizy i interpretacji Mitosek określa mianem „poetyki genetycznej”. Zob. Zofia Mitosek, „Morał i historia (transformacje sensu w genezie «Bram raju» Jerzego Andrzejewskiego”, w Ecriture / Pisanie. Materiaty z konferencji polsko-francuskiej, Warszawa, październik 1992, red. Zofia Mitosek i Jakub Zdzisław Lichański (Warszawa: Wydawnictwo DiG, 1995), 41-49.

${ }^{5}$ Przykładem może tu być analiza brulionowej historii dramatu Jerzego Zawieyskiego pt. Gdy płoną lasy, przeprowadzona przez Olgę Dawidowicz-Chymkowską, pokazująca stopniowe odchodzenie twórcy od, stanowiącego dlań punkt wyjścia, epickiego modelu dramatu (i teatru). Zob. Olga Dawidowicz-Chymkowska, Przez kreślenie do kreacji. Analiza procesu twórczego, zapisanego w brulionach dzieł literackich (Warszawa: Wydawnictwo IBL, 2007), 230-284. Inne, nieco nowsze przykłady „genetycznej poetyki dramatu”: Anna R. Burzyńska, Praca na rzeczywistości. Ślady dokumentalności w procesie twórczym „Lalka”; Anna R. Burzyńska, „Pomysł w kształcie trójkąta”, czyli „Trzy lekcje lustra”; Mateusz Antoniuk, Historia „Drugiego pokoju” (z autorskim komentarzem); Mateusz Antoniuk, Między intencją i realizacją. Powstawanie dramatu „Baśn zimowa”, wszystkie wymienione szkice w Pracownia Herberta. Studia nad procesem tekstotwórczym, red. Mateusz Antoniuk (Kraków: Wydawnictwo Uniwersytetu Jagiellońskiego, 2017); Mateusz Antoniuk, „ «Bebeszenie (się) dramatu», albo «jakże to Herbert pisywał...». O powstawaniu dramatu sokratejskiego", w Archiwa i bruliony pisarzy. Odkrywanie, red. Maria Prussak, Paweł Bem i Łukasz Cybulski (Warszawa: Wydawnictwo IBL, 2017), 217-255.

${ }^{6}$ Por. koncepcja poetyki jako „języka-pośrednika”, sformułowana przez Stanisława Balbusa w szkicu „Granice poetyki i kompetencje teorii literatury", w Poetyka bez granic, red. Włodzimierz Bolecki i Wojciech Tomasik (Warszawa: Wydawnictwo IBL, 1995), 16. 
Zaczynam więc jeszcze raz. Po co poetyce - genetyka? Można przecież sceptycznie zauważyć: istnieje na świecie dostatecznie wiele tekstów skończonych i opublikowanych, na których da się przeprowadzać operacje z zakresu stylistyki (i stylometrii), narratologii albo wersologii, testując jeszcze raz te same, gdzie indziej już wypraktykowane, instrumenty, potwierdzając ich operatywność. Czy wyprawa w prepublikacyjne, brulionowe dzieje utworu skutkuje tylko odczuciem déjà vu (znów to samo!, to już było!), czy stwarza jakąś „nową sytuację poetyki”??

Jedna z możliwych odpowiedzi na pytanie o genetyczny wkład w ekonomię poetyki brzmi, jak sądzę, następująco: przeniesienie uwagi z tekstu in actu na tekst przychwytywany in statu nascendi może pomóc poetyce w spełnianiu jej głębokich aspiracji, w realizacji jej pragnienia.

Czego „chce” poetyka? Zapewne - różnych rzeczy. Ale jedno z jej pragnień da się wyczytać z takiej oto definicji, sformułowanej w roku 2013 przez Dorotę Korwin-Piotrowską:

Pojęcia z zakresu poetyki są zapisem poznawczego wysiłku, by zbadać i opisać pracę ludzkiego umysłu, wyobraźni oraz języka zawartą w prozatorskiej bądź poetyckiej wypowiedzi jako procesie wydobywania na powierzchnię jednych znaczeń kosztem innych, sugerowania migotliwego sensu za pomocą skończonej ilości jednostek; „wyistaczania się”, mówiąc językiem Heideggera, jakiegoś świata w słowie8.

Definicja, zwłaszcza kiedy jest formułowana niejako „z wnętrza” definiowanego zjawiska (a właśnie taka sytuacja tu zachodzi, poetykę definiuje wszak badaczka intensywnie ją praktykująca i teoretyzująca), stanowi tyleż deskrypcję, co projekcję, czyli ujawnienie pragnień. Ta poetyka, której obraz wyłania się z cytowanej definicji, chce korelować wysiłek („poznawczy”, powiada Korwin-Piotrowska, ale przecież wolno nam dodać: i twórczy, skoro poznanie jest tworzeniem) skumulowany w poetologicznej glosie z wysiłkiem (twórczym, a skoro tak, to i poznawczym), skumulowanym w konkretnym, jednostkowym tekście, do którego odnosi się poetologiczna glosa. Poetyka, inaczej mówiąc, chce być pracą odpowiadającą na pracę. Otóż sądzę, że właśnie to „pragnienie poetyki” zyskuje szansę nowej, pogłębionej, jakoś pełniejszej realizacji wówczas, gdy poetyka staje się „poetyką genetyczną”, czyli taką, która swe pole obserwacji rozciąga na archiwum procesu tekstotwórczego. Co też spróbuję wykazać w niniejszym artykule.

Będę się starał przedstawić in praxis, w jaki sposób problem „pracy ludzkiego umysłu” może stać się poznawczo dostępny, więcej nawet, pierwszoplanowy, dla poetyki genetyką podszytej. Spróbuję pokazać, jak i w jakim stopniu jest to możliwe wówczas, gdy przedmiotem obserwacji stanie się pewna formalna właściwość tekstu (skądinąd: raczej nieuznawana za najbardziej skomplikowany czy intelektualnie stymulujący problem poetologiczny). Mianowicie - rym.

\footnotetext{
${ }^{7}$ Nawiązuję tu do formuły ukutej przez Tomasza Mizerkiewicza w artykule inaugurującym działalność pisma „Forum Poetyki”. Mizerkiewicz przekonująco określa w nim poetykę mianem „wiedzy sytuacyjnej”, podkreślając, że jest ona teorią i praktyką, która powinna nieustannie „sprawdzać się” w kontakcie z coraz to innymi fenomenami „tekstowego świata”, czyli pozostawać w czujnej gotowości do weryfikowania, poszerzania i modyfikowania swoich dotychczasowych uzusów i słowników. „Nowymi sytuacjami poetyki” byłyby więc wszelkie zastosowania, które działają stymulująco, prowokują do autoredefinicji, a nie jedynie utwierdzają tożsamość już zdobytą czy skonstruowaną. Zob. Tomasz Mizerkiewicz, „Nowe sytuacje poetyki”, Forum Poetyki, lato 2015: 18-23, http://fp.amu.edu.pl/lato-2015-20151/(dostęp: 10.08.2020).

${ }^{8}$ Dorota Korwin-Piotrowska, „Życie pośmiertne poetyki”, Tematy i Konteksty, nr 3 (2013): 28.
} 


\section{Poetyka (genetyczna) rymu}

Rym - pod takim tytułem ukazała się w roku 1972 książka Lucylli Pszczołowskiej ${ }^{9}$ Publikacja, stanowiąca kolejną odsłonę serii „Poetyka. Zarys encyklopedyczny”, firmowanej przez Instytut Badań Literackich PAN, jest znaczącym dokonaniem polskiego strukturalizmu w zakresie poetyki opisowej i historycznej, nadal budzi szacunek spójnością i kompletnością wywodu. Rym (rozumiany jako współbrzmienie międzywyrazowe) ujmowany jest tu, kolejno, jako zagadnienie z zakresu prozodii, fonetyki i morfologii, leksyki oraz semantyki języka, jako problem rozpatrywany z punktu widzenia badań nad składnią zdania oraz studiów nad kompozycją tekstu artystycznego. Ujęcie synchroniczne (wyrażające się na przykład w tabeli, modelowo klasyfikującej polski rym ze względu na jego konstrukcję fonetyczną) splata się z ujęciem diachronicznym (zajmująca połowę książki część ostatnia, opisująca rym jako historycznie zmienną konwencję literacką). Dyskurs językoznawczy spotyka się z dyskursem literaturoznawczym, ten ostatni zaś stara się uzyskać maksymalną możliwą rozpiętość referencyjną: od praktyk rymowych wczesnego średniowiecza do praktyk rymowych Mirona Białoszewskiego.

Czy książka ta jest zapisem wysiłku poznawczego włożonego w próbę zrozumienia i opisania pracy twórczego umysłu, w tym wypadku - umysłu rymującego? Wysiłek poznawczy monografia Rym niewątpliwie wyraża; jest to na przykład wysiłek klasyfikowania (tworzenia kryteriów klasyfikacji, następnie zaś ich stosowania do konkretnych kazusów) i wysiłek obliczania (ustalania i analizowania danych liczbowych, dotyczących frekwencji występowania różnych typów rymu w twórczości wybranego autora, w określonym zakresie czasowym etc.). Wysiłek ów wykonany został oczywiście przez Pszczołowską. Ale też można powiedzieć, że w książce znakomitej autorki spożytkowany został wysiłek poznawczy wielu różnych szkół i wielu różnych badaczy, którzy - co najmniej od lat 20. ubiegłego stulecia - budowali „w świetle językoznawstwa" gmach nowoczesnej poetyki. Formalizm i praski strukturalizm (z Jakobsonem, Tomaszewskim, Mukařovskim na czele ${ }^{10}$ ), międzywojenne i powojenne prace polskich badaczy wiersza (m.in. Nitsch, Siedlecki, Furmanik, Dłuska, twórcy słowników rymów Mickiewicza i Trembeckiego ${ }^{11}$ ) - całe to szerokie zaplecze książki Pszczołowskiej wnosi do niej swój wysiłek poznawania. Czy jednak wysiłek ów nakierowany jest na pracę rymotwórczego umysłu? Sądzę, że nie, a w każdym razie - nie bezpośrednio. Przedmiotem poznawanym jest tu bardziej gotowy wytwór, rym, który już jest (np. jest „asonansem z alternacją spółgłoski interwokalicznej” albo jest „konsonansem z alternacją samogłoski poakcentowej”), niż intelektualny, psychologiczny, somatyczny wysiłek, mający na celu ustanowienie brzmieniowych korespondencji

${ }^{9}$ Lucylla Pszczołowska, Rym (Wrocław: Zakład Narodowy im. Ossolińskich - Wydawnictwo Polskiej Akademii Nauk, 1972). Dokładna lokalizacja książki w serii wydawniczej jest następująca: Poetyka. Zarys Encyklopedyczny, Dział III Wersyfikacja, tom II Wiersz. Podstawowe kategorie opisu, część II Eufonia, zeszyt 1 Rym.

${ }^{10}$ Roman Jakobson, „O lingwistycznej analizie rymu”, Prace Filologiczne XVIII (1963): 47-52; Boris W. Tomaszewski, „Przyczynek do historii rymu rosyjskiego”, w Rosyjska szkoła stylistyczna, red. Maria Renata Mayenowa i Zygmunt Saloni (Warszawa: Państwowy Instytut Wydawniczy, 1970): 55-63; Jan Mukařovský, „O języku poetyckim”, w: Praska szkoła strukturalna w latach 1926-1948. Wybór materiatów (Warszawa: Państwowe Wydawnictwo Naukowe, 1966): 130-206.

${ }^{11}$ Kazimierz Nitsch, „O nowych rymach”, „O rymach głębokich i niezupełnych”, „Z historii polskich rymów”, w Kazimierz Nitsch, Wybór pism polonistycznych (Wrocław: Zakład Narodowy im. Ossolińskich, 1954); Franciszek Siedlecki, Studia z metryki polskiej, cz. 2, Problem transakcentacji w wierszu polskim (Wilno: z zasiłku Funduszu Kultury Narodowej, 1937); Stanisław Furmanik, „Rym”, w Stanisław Furmanik, Z zagadnień wersyfikacji polskiej (Warszawa: Państwowe Wydawnictwo Naukowe, 1956); Maria Dłuska, Studia z historii i teorii wersyfikacji polskiej, t. 1 i 2 (Kraków: PAU, 1948-1950). 
między wybranymi słowami. Rym, zgodnie zresztą z tytułem książki, jest tu w centrum uwagi. Rym - a nie rymotwórstwo.

Pojęcie „rymotwórstwa” czerpię ze Sztuki rymotwórczej, słynnego, wierszowanego traktatu Franciszka Ksawerego Dmochowskiego z roku 1788. Interesuje mnie ten traktat, gdyż kładzie on silny nacisk na status rymu jako artefaktu, który wymaga wytworzenia, wypracowania: poetę nazywa się tam „rymotwórcą”, tworzenie poezji - „rymotwórską robotą”. Oczywiście, pamiętam o tym, że wyraz „rym” w polszczyźnie aż do XIX wieku oznaczał nie tylko brzmieniową zgodność wyrazów w wierszu, lecz również, synonimicznie, cały wiersz ${ }^{12}$ - pisząc o „tworzeniu rymu” jako o „robocie”, Dmochowski może więc pisać ogólnie o tekstotwórczości poetów. Są jednak takie passusy w XVIII-wiecznym traktacie, które bez wątpienia odnoszą się do rymu rozumianego jako współbrzmienie wyrazów ulokowanych w klauzulach wersów i które wyraźnie eksponują właśnie ów aspekt wysiłku, trudu, pracy.

Rzecz ciekawa, co do zalecanego (Sztuka rymotwórcza jest wszak poetyką normatywną i postulatywną) stopnia wysiłku, jaki należy włożyć w „robotę rymowania”, Dmochowski wykazuje się lekką niekonsekwencją. W początkowych partiach swego poematu zdaje się głosić pochwałę pracy, by tak rzec, „niskokosztowej”:

Jaką rzecz przedsiębierzesz, trefną czy wysoką,

Zawsze na rymowanie chciej baczne dać oko,

By naturalne było, bez żadnej przysady.

Gdzie rym dużo kosztuje, nie będzie bez wady.

Komu trudno przychodzi w rym związać dwa słowa,

Tego - jeźli ma dowcip - wolna wzywa mowa;

Wiersz go nie chce, bo musu żadnego nie lubi ${ }^{13}$.

Już jednak pod koniec Pieśni Pierwszej wprowadzona zostaje myśl jakby odmienna, przestrzegająca przed ryzkiem zbytniej łatwości, dowartościowująca trud i długotrwałość rymotwórczej pracy:

Pracuj na osobności, bez zgiełku, hałasu.

Trzeba, żeby co zrobić, i miejsca, i czasu.

Niechaj cię próżnej chwały nie zwodzą pozory,

Nie szukaj z tego chluby, żeś w pisaniu skory.

Rzadki ten, co i dobrze, i prędko napisze,

Zatem, wy, co piszecie, mili towarzysze,

Nadto czasu w pisaniu łożyć nie możecie,

Jeżeli prawdziwej chwały dostąpić pragniecie.

[...]

Pośpieszaj, ale zwolna. Pisz ostrożnie rymy.

Nie leń się ich dwadzieścia razy wziąć do limy.

Nie trać serca w robocie, zniknie trudność z pracą,

A nic na opóźnieniu twe dzieła nie stracą.

${ }^{12}$ Pszczołowska, Rym, 78.

${ }^{13}$ Franciszek Ksawery Dmochowski, Sztuka rymotwórcza (Wrocław: Zakład Narodowy im. Ossolińskich, 1956), 12. 
Czemu dziś nie wydołasz, nazajutrz dokażesz,

$\mathrm{Z}$ czasem przydasz, co trzeba, a co nadto, zmażesz ${ }^{14}$.

Poetyka, która pragnie być badaniem pracy tworzącego umysłu i która wejdzie w metodologiczną kooperację z genetyką - poetyka genetyczna, krótko mówiąc - może faktycznie brać za swój przedmiot poznania wszystko to, o czym pisze w cytowanych wyżej wersach oświeceniowy prawodawca. Czas wypracowywania rymu, „dziś” oraz „nazajutrz” rymotwórczej akcji, jej przyspieszenia i spowolnienia, „koszt”, pojęty jako nakład pracy włożonej w „rymotwórstwo”, rezygnacje z tego, co już wypracowane, i poszukiwanie odmiennych dróg - to właśnie staje się doświadczalne dla genetycznej poetyki rymu.

Być może da się wyodrębnić dwa (niekoniecznie skonfliktowane, raczej, potencjalnie, komplementarne) modele uprawiania poetyki rymu: poetykę wytworu i poetykę wytwarzania. Ta pierwsza - głosem akademickiego podręcznika - definiuje: „Rym w wierszu polega na częściowej lub całkowitej zgodności brzmienia zakończeń wyrazów zajmujących określoną pozycję $\mathrm{w}$ wersie" ${ }^{15}$. Tę drugą interesują wyrazy, których pozycja w wersie nie jest jeszcze określona, lecz ruchoma; „zgodność brzmień” ciekawi ją zaś jako konsensus w toku negocjowania. Poetyka wytworu, przyglądająca się wierszowi już zrobionemu, widzi (i słyszy) rym - przepraszam za tautologizm - zrymowany; opisuje coś, co jest, jakie jest i co stanowi formalną cechę napisanego tekstu, jego konstrukcyjny element. Poetyka wytwarzania, która spotkała na swej drodze genetykę (albo mocniej: poetyka, która genetyce dała się sprowadzić na manowce voyeryzmu), widzi (i słyszy) nie tyle nawet rym, co rymowanie. Jej przedmiotem poznania staje się sama czynność nawiązywania brzmieniowych ekwiwalencji między wybranymi jednostkami tekstu. Oraz wysiłek - zawsze jest jakiś wysiłek! - z którym wykonywanie owej czynności się wiąże.

Współpracę obu tych poetyk spróbuję zademonstrować na konkretnym przykładzie.

\section{Jak jest zrobiony rym Miłosza? A jak - był robiony?}

Oto dwa wiersze Czesława Miłosza: jeden zatytułowany Rozmowy na Wielkanoc 1620 roku i drugi - Na ścięcie damy dworu ${ }^{16}$. Utwory te wiele łączy. Pod obydwoma Miłosz zamieścił w druku tę

\footnotetext{
${ }^{14}$ Dmochowski, 31-32. Jak na ironię, jeden z wersów fragmentu głoszącego konieczność pilnej cyzelatury wydrukowany został błędnie. „Jeżeli prawdziwej chwały dostąpić pragniecie” - oczywiście wers jest za długi o jedną sylabę, tak jednak poemat brzmi w pierwszym wydaniu. Późniejsze wydania wprowadzały w to miejsce emendację „jeźli”. Współczesna edycja, za którą cytuję dzieło Dmochowskiego, opiera się jednak na najwcześniejszym przekazie drukowanym, informując tylko w przypisach o jego usterkach i późniejszych korekturach.

${ }^{15}$ Michał Głowiński, Aleksandra Okopień-Sławińska, Janusz Sławiński, Zarys teorii literatury (Warszawa: Państwowe Zakłady Wydawnictw Szkolnych, 1972), 211. Podobnie brzmi definicja w nowym kompendium: „Rym współdźwięczność występująca w zakończeniach par wyrazów, zabieg polegający na zestawianiu ze sobą wyrazów o powtarzających się na końcach zespołach głosek (tzw. komponentach rymowych)". Dorota Korwin-Piotrowska, Poetyka: Przewodnik po świecie tekstów (Kraków: Wydawnictwo Uniwersytetu Jagiellońskiego, 2011), 281.

${ }^{16}$ Jedną z rzeczy, które szczególnie pasjonują mnie w genetyce, jest jej połączenie z interpretacją tekstu, tak też starałem się - najczęściej - uprawiać krytykę genetyczną wierszy, dramatów, prozy fabularnej i eseistycznej. Akurat w niniejszym szkicu operacji stricte interpretacyjnych nie wykonuję wcale. Dlatego też nie przywołuję istniejących, ważnych i ciekawych odczytań obu wierszy Miłosza. O jednym szkicu nie sposób jednak nie wspomnieć - wybitną analizę poetologiczną (formalną) wiersza Rozmowy na Wielkanoc 1620 roku, skupioną na stylizacyjnych zabiegach Miłosza, a zarazem ściśle splecioną z praktyką interpretacji, przeprowadził Stanisław Balbus. Choć akurat zagadnieniom związanym z rymami analiza ta nie poświęca wiele miejsca. Zob. Stanisław Balbus, Między stylami (Kraków: Towarzystwo Autorów i Wydawców Prac Naukowych „Universitas”, 1993), 53-64.
} 
samą informację paratekstową: „Montgeron 1959”. Oba miały pierwodruk na łamach „Kultury” w roku 1960, w numerze 5. Oba zostały przez Miłosza włączone do zbioru zatytułowanego Król Popiel i inne wiersze z roku 1962. Zatem - mamy tu do czynienia z tekstami pochodzącymi z jednej i tej samej fazy Miłoszowej twórczości (i to fazy rozumianej wąsko, precyzyjnie). I wreszcie: oba te wiersze są rymowane.

Pozwólmy przemówić im teraz pełnym głosem.

\section{Rozmowy na Wielkanoc 1620 roku}

- Waść teraz jesteś jako mucha w dzbanie.

Winem opita łapkami wiosłuje.

$\mathrm{Z}$ niej tyle samo co $\mathrm{z}$ waści zostanie,

Darmo nadzieja frasunki cukruje.

Złociste guzy, kiereje i stroje

W skrzyniach jaśnieją, a śmierć mówi: moje.

Spódnice dziewkom waść zawijać raczył,

W gaju brzozowym biegał $\mathrm{z}$ twardą pytą.

Sekreta jakie możeś tam zobaczył?

Albo gdy konia pod tobą ubito,

Umazanemu bitewną posoką

Mądrość odkryło słupiejące oko?

Pies, koń i owad, zwierz leśny i polny

Żyją i giną, a ty chcesz trwać wiecznie?

Jak one mocom nie swoim powolny

Krucyfiks chwytasz, bo tak ci bezpiecznie.

Drewno masz w ręku, a w tym drewnie próchno.

Pacierze mruczysz, ale strachem cuchną.

Już gęba twoja oddarta od kości

I w czarnym mięsie robak fossy ryje.

Nie, panie bracie, nie będzie wieczności,

Jej nie kupiły błagania niczyje.

Choć patrzysz w okno, czy nie dane znaki,

Tobie i bydłu przypadek jednaki.

- Ani ja wierzę w duszę nieśmiertelną,

Ani nagrody czekam dla zasługi.

Imię i pamięć z szatą mi odejmą,

Wiek mój skończony i wiek mój niedługi.

A kiedy, pusty, legnę sam w mogile,

Na nieskończone czasy, nie na chwilę.
Lecz jako Bóg mnie postawił na ziemi, Jeżeli zechce, znowu mnie postawi.

Nie mnie dochodzić, u jakich płomieni, W jakich kuźnicach serce mi przetrawi, Ani zgadywać, w roku czy godzinie

On się objawi, kiedy świat przeminie.

Gdybym nie ufał słowu Boga mego,

Za cóż ufają ludzie słowom ludzi?

Może nie świętych, ale nikczemnego

Swoją miłością do chwały przebudzi

I proch połączy niepojętą siłą,

Aby co skryte wyjawione było.

A jeśli dla mnie dola zgotowana

Wróbla i kruka, liszki i łasicy,

I, nocny motyl, nie doczekam rana,

Ale zgoreję cały w ogniu świécy,

Jeślim nie po to, żeby mnie ocalił,

Przecie do końca Jego będę chwalił.

- Waść kalwin. Proszą kłaniać się Kiejdany.

Jedźże z pospólstwem tam zawodzić DIEVIE

Albo kazania słuchać z Angliczany

W zborze bielonym, zgoła niby chlewie.

Kiedy herezja dotąd w tobie siedzi,

Co z wielkanocnej waścinej spowiedzi?

W dolinę tedy idziesz Jozafata?

A czyś pomyślał, jacy tam królowie

I narodzonych w nieobeszłe lata

Jakich tam ludów nazbiera się mrowie?

Jakie tam śpieszą tysiąców tysiące,

Straszne machiny, smoki latające? 
Jakie przestwory i jakie marmury, Jakie rozumy, jakie palmy święte. Ów cuda czynił i przenikał mury, Tamten Sodomy zratował wyklęte. Mitry papieskie, berła, pastorały Wyżej od Alpów tam będą leżały.

Gdzie sprawiedliwych, zgromadzonych w domie, Hyzopem, myrrą witają anioły,

Gdzie lekkie duchy stąpają widomie, Potrzeba jeszcze durnia z Wędziagoły, Który gniótł dziewki, znał myślistwo ptasze? I jakże tobie nie wstyd, powiedz, wasze.

- Iżem niegodny i pokornej cześci Maluczkich, biednych szanować nie umiał, Ja pod majestat chronię się niewieści, Bom więcej pragnął, niżeli rozumiał. Maryi Matki warga moja wzywa.

Niech mnie gwiazdami swoimi okrywa.

A jeśli w bramę ostatniej doliny

Zastuka za mnie kij mego pasterza, Nie dbam, ku czemu wezmę obłóczyny Pomny obietnic wiecznego przymierza. Po Jego woli przybranie dostanę, Nie ciało szpetne, dawno zapomniane.

Przez kraje wschodu i kraje zachodu, Ziemie południa i ziemie północy Dzieckiem pobiegnę w świetle do ogrodu Jutrzenną porą po nawalnej nocy. Wzrok, smak i dotyk nie takie posiędę, Lepszych niż tutaj muzyk słuchać będę.

Grecką, egipską odezwę się mową I wszelką, jaka była od początku. Księgę Rodzaju odczytam na nowo, Świadom splątanej osnowy i wątku. I każdą poznam tajemną przyczynę. A potem w Jego szczęśliwości zginę ${ }^{1}$.

\section{Na ścięcie damy dworu}

Migdałowe anioły z obłokiem woalki, Co nigdy nie kucają pomiędzy pokrzywą, Ciało bez dziurek mają, gładkie jak u lalki I nikt ich nie potrafi zaprosić na piwo.

Tak mi się ukazały wtedy, chłopcu z wioski. Rżały konie, łęk siodła spod rękawic błyskał. I podniosłem w ukłonie kapelusz ojcowski. A one przeleciały, huczał śmiech jak wystrzał.

Suczko. To jakże teraz. Jęzor swój różowy Zwiesiłaś, pełznąc do mnie bez farb ni przepaski. I na czworakach, futrem kędzierzawej głowy U mojego trzewika dopraszasz się łaski?

A czemu byłaś posąg, skoro jesteś cieniem I frufru twoich spódnic latami mnie piekło? Niech to, za czym goniłem, będzie zapomnieniem. To jabłko niech od mojej gałęzi odetną.

Dziś ja wielki, największy z całego powiatu Ogłosić mogę wyrok. Służba. Dać ją katu². 


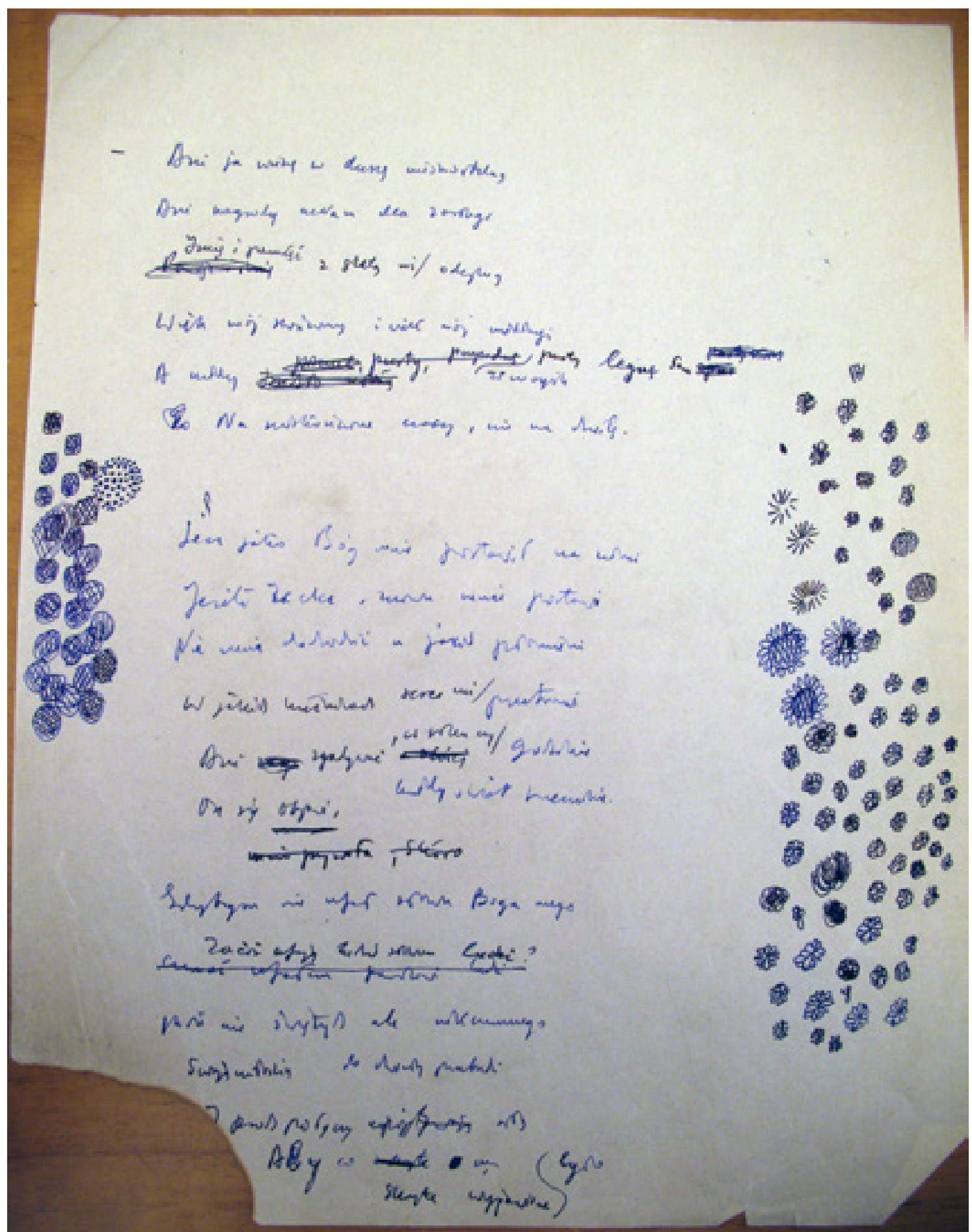

Ilustracja 1: Brulion wiersza „Rozmowy na Wielkanoc 1620 roku” (praca nad strofą V i VI), Beinecke Rare Book and Manuscript Library, Yale University

Opisowa poetyka rymu, poproszona o ekspertyzę dotyczącą tych dwu wierszy, mogłaby, jak są$\mathrm{dzę,} \mathrm{powiedzieć} \mathrm{tak:} \mathrm{cytowane} \mathrm{in} \mathrm{extenso} \mathrm{utwory} \mathrm{mają} \mathrm{dwa} \mathrm{odmienne} \mathrm{układy} \mathrm{rymowe.} \mathrm{Odmien-}$ ne, choć - tu akurat pozwolę sobie na moment nieakademickiego figlarstwa, nieprofesjonalnej dezynwoltury - takie same. Pierwszy utwór pisany jest klasyczną jedenastozgłoskową sekstyną typu ababcc, drugi to prosty wiersz stroficzny, oparty na zwrotce czterowersowej, rymowany 
abab, $\mathrm{z}$ trzynastozgłoskowym formatem sylabicznym. Ale puentę tego drugiego wiersza Miłosz zdecydował się ująć w formę dystychu spiętego rymem sąsiadującym. Poniekąd można więc powiedzieć, że oba liryki realizują schemat ababcc, tyle że w pierwszym z nich cc wydarza się wielokrotnie, w wygłosie każdej zwrotki, w drugim - tylko raz, w wygłosie całego wiersza. Identyczna jest też, oczywiście, sama reguła rymowania słów: w obu wierszach Miłosz używa rymów paroksytonicznych, w przeważającej mierze dokładnych i, poza nielicznymi wyjątkami, otwartych (czyli z samogłoskowym wygłosem wyrazów); na ich tle zaznaczają się rymy niedokładne: np. konsonans „pytą - ubito” w Rozmowach... czy asonans "piekło-odetną" w Na ścięcie damy dworu. Poetyka „statyczna” mogłaby przeprowadzić bardziej jeszcze zaawansowaną ekspertyzę: zejść na detaliczny poziom opisu fonetycznego (i, na przykład, zauważyć, że rozpatrywanemu wyżej asonansowi towarzyszy alternacja spółgłoski interwokalicznej), dodać poziom opisu gramatycznego (i za klasyfikacją Pszczołowskiej, opartą z kolei na kryteriach Jakobsona, wprowadzać dystynkcje na rymy gramatyczne pełne, półgramatyczne, formalnie gramatyczne oraz antygramatyczne), podać dane statystyczne na temat dystrybucji poszczególnych typów rymu w obrębie całego tekstu, jak i poszczególnych strof. Mogłaby też działać na zasadzie tłumacza, pośredniczącego między różnymi terminologiami i koncepcjami klasyfikowania zjawiska rymu ${ }^{17}$. Tak czy inaczej, poetyka dynamiczna, poetyka wytwarzania, zaczyna swoje dociekania tam, gdzie poetyka wytworu je zakończyła - i pyta o proces strukturyzowania struktury rymowej ${ }^{18}$.

Ilustracja nr 1 przenosi nas ona in medias res brulionowej historii wiersza Rozmowy na Wielkanoc 1620 roku $^{19}$. Spoglądamy mianowicie na reprodukcję trzeciej (z siedmiu) kart. Krótka Vorgeschichte: na dwóch pierwszych kartach Miłosz pracował nad strofą pierwszą, drugą, trzecią i czwartą. Proces wytwarzania tekstu przebiegał ze zmienną dynamiką: niektóre wersy pojawiały się na karcie bez takich znaków wahania, kluczenia, wątpliwości, jak skreślenia, nadpisania, adnotacje w interliniach, inne wymagały jakby pokonania większych oporów, wyłaniały się w drodze bardziej mozolnych studiów. Zasadniczo jednak proces pisania przebiegał bez silnych wyhamowań, zakleszczeń - raz „szybszy”, raz „powolniejszy”, rozwijał się linearnie, wers po wersie, strofa po strofie, bez nawrotów, restartów, zmieniania kolejności wypracowanych już jednostek kompozycyjnych.

„Teraz” (na dokumencie, który właśnie poznajemy za pośrednictwem ilustracji nr 1) proces pisania dociera do strofy piątej, następnie zaś szóstej. Właśnie ta sekwencja tekstotwórczej akcji będzie nas interesować, w niej bowiem zachodzi zjawisko szczególnie ciekawe z punktu widzenia poetyki genetycznej.

\footnotetext{
${ }^{17}$ Monografia Pszczołowskiej rezygnuje na przykład z operowania kategorią „rymu bogatego”, którą posługuje się, chociażby, Zarys poetyki Adama Kulawika, Ewy Miodońskiej-Brookes i Mariana Tatary.

${ }^{18}$ Poezja Czesława Miłosza była już przedstawiana w perspektywie krytyki genetycznej, por. Mateusz Antoniuk, Słowo raz obudzone. Poezja Czesława Miłosza - próby czytania (Kraków: Księgarnia Akademicka, 2015), 79-117; Mateusz Antoniuk, „Przybranie formy z dawna wyglądanej (dosięganej / obiecanej / wysnowanej...). Brulion Czesława Miłosza - próba lektury”, Teksty Drugie, nr 3 (2014): 29-48; Mateusz Antoniuk, „Miłoszologia i krytyka genetyczna (rekonesans)", Świat i Stowo 25, nr 2 (2015), 112-133. O wizualnych aspektach brulionów Miłosza pisały Bożena Shallcross oraz Karina Jarzyńska (do tych ujęć odwołuję się w dalszej części szkicu, por. przyp. 26 i 27). Wymienione prace dotyczą prepublikacyjnej dynamiki tekstu; istnieje natomiast odrębna monografia, poświęcona w głównej mierze modyfikacjom (częściowo zamierzonym przez autora, częściowo zaś niezwiązanym z intentio auctoris), jakim podlegały wiersze Miłosza w kolejnych edycjach i przedrukach - mowa o książce: Paweł Bem, Dynamika wariantu. Miłosz tekstologicznie (Warszawa: Wydawnictwo IBL, 2017).

${ }^{19}$ Bruliony tego wiersza znajdują się w Beinecke Rare Book and Manuscript Library (Yale University). Dokładna lokalizacja: Czesław Miłosz Papers, Series II: Writings, Box 83, Folder 1108.
} 
Na początek zwróćmy uwagę na niejednolitość inskrypcji: niektóre wyrazy naniesione zostały atramentem jasnym, niektóre atramentem ciemnym. Dokument ma sześćdziesiąt lat, jego kolorystyka musiała, w jakiejś mierze, zmienić się na skutek zachodzących reakcji chemicznych, nie ulega jednak wątpliwości, że Miłosz operował tu dwoma różnymi atramentami, które także dziś, po sześciu dekadach, pozwalają rozróżnić dwie fazy pracy nad tekstem: atrament jaśniejszy odpowiada mianowicie fazie pierwszej, wcześniejszej, atrament ciemniejszy odpowiada fazie drugiej, późniejszej. Zyskujemy tym samym szczególną sposobność - możemy precyzyjnie rozwarstwić zapis i odtworzyć w wyobraźni wygląd rękopisu między pierwszą a drugą fazą, zrekonstruować przejściową postać tekstu (już nie biała karta, a jeszcze nie ten zapis, który widzimy dziś).

Pierwotny rzut obu sekstyn, sporządzony jaśniejszym atramentem, przedstawiał się następująco:

- Ani ja wierzę w duszę nieśmiertelną

Ani nagrody szukam dla zasługi

odejmą

Wiek mój skończony i wiek mój niedługi

A kiedy w mogile

To Na nieskończone czasy, nie na chwilę.

Lecz jako Bóg mnie postawił na ziemi

Jeżeli zechce, znowu mnie postawi

Nie mnie dochodzić u jakich płomieni

przetrawi

godzinie

kiedy świat przeminie

Teraz już widzimy to wyraźnie: dochodząc w pierwszym zapisie do wersu trzeciego i piątego sekstyny piątej oraz czwartego, piątego i szóstego sekstyny szóstej, Miłosz jakby wybiegał naprzód, uprzedzał linearny przyrost sylab i słów; wszystko po to, by najpierw rozwiązać problem rymu oraz klauzuli, odraczając tym samym rozwiązanie problemu „wnętrza” wersu. Czynił tak zarówno wówczas, gdy zadanie polegało na dokończeniu rymowania (znalezieniu współbrzmienia dla wyrazów już w wierszu usytuowanych: „nieśmiertelną” w sekstynie piątej, „postawi” w sekstynie szóstej), jak i wtedy, gdy należało rymowanie zacząć (czyli usytuować wyraz, do którego będzie należało dopasować wyraz współbrzmiący: „mogile” w sekstynie wcześniejszej, "godzinie” w sekstynie późniejszej). Do powstałych w ten sposób pustych miejsc poeta wrócił później (o ile później? tego, oczywiście, nie wiemy) i pracował nad ich wypełnieniem w toku odrębnej sesji pisarskiej, mając już w ręku inne pióro, napełnione innym, ciemniejszym atramentem. Co ciekawe, te same dwa atramenty da się też wyróżnić w rysunkach wykonywanych przez Miłosza na marginesach brulionu. Zarówno „kwiatki” (dominujące na marginesie prawym), jak i figury geometryczne (dominujące na marginesie lewym) łatwo podzielić na te jaśniejsze (odcień identyczny z zapisem wyrazów na pozycjach rymowych) oraz ciemniejsze (paralelne kolorystycznie do „wypełnień” wersów); dokładny ogląd pozwala nawet zauważyć doodles jaśniejsze, „przejechane” po raz drugi kreską ciemniejszą. Obie fazy pisania mają więc swoje rysunkowe korelaty. 
Koniec końców inskrypcja uzyskała ten kształt, który widzimy na ilustracji nr 1, a który usiłuje zademonstrować poniższa transliteracja, odzwierciedlająca możliwie wiernie przestrzenny układ zapisu (położenie słów względem siebie nawzajem i względem osi kartki) ${ }^{20}$. Dopiski sporządzone ciemniejszym atramentem oddaję za pomocą pisma pogrubionego, wyrazy nieczytelne oznaczam kwadratowymi nawiasami z kropkami, skreślenia - za pomocą czcionki przekreślonej (rysunki zostały pominięte ze względów technicznych).

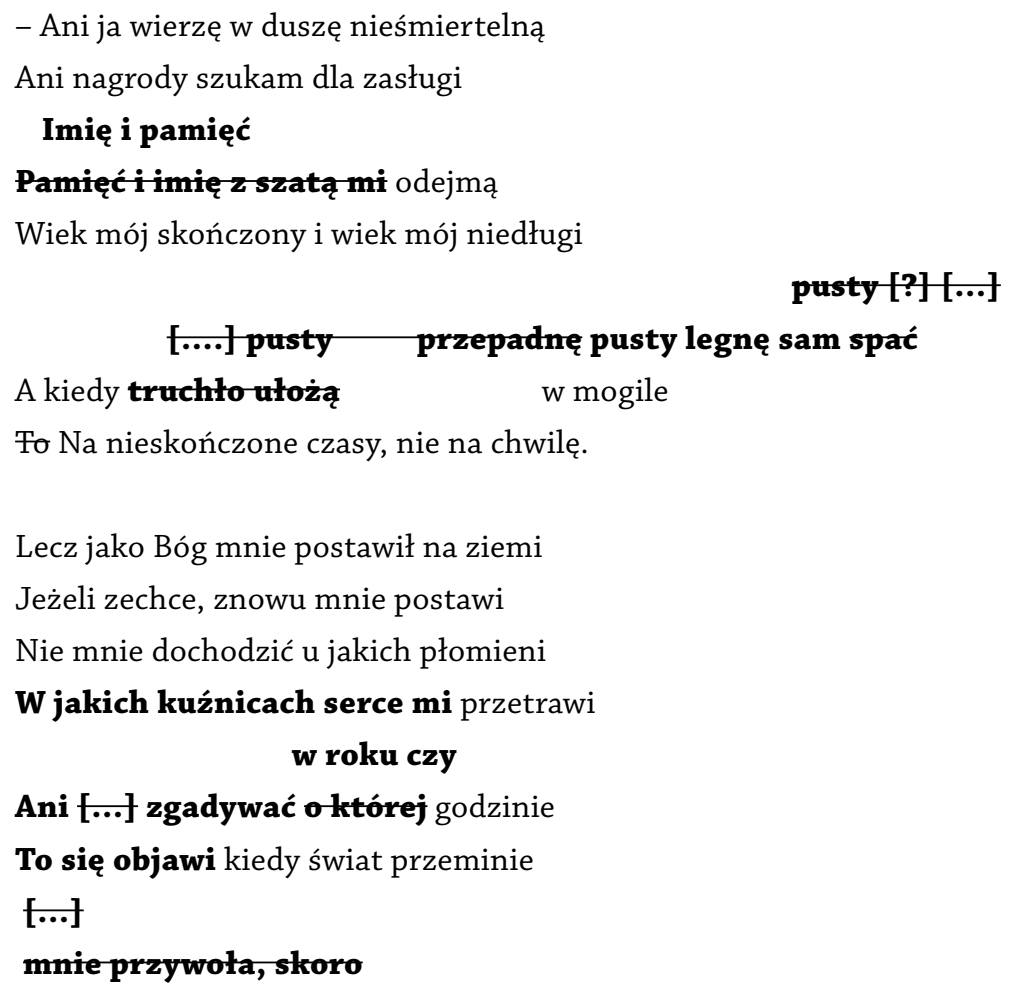

Zauważmy: żadne ze słów „klauzulowych”, zapisanych w pierwszej fazie wytwarzania tekstu, nie zostało przekreślone i zastąpione innym słowem; jeśli gdzieś dokonywały się jakieś zmiany, to we „wnętrzu” wersów. Z żadnego z wypracowanych rozwiązań rymowych Miłosz się nie wycofał - ani w tym brulionowym autografie, ani na późniejszych etapach procesu tekstotwórczego, ani w trakcie przygotowywania tekstu do druku. Rymy uchwycone w pierwszym, brulionowym zapisie znajdziemy w utworze opublikowanym. A dodajmy: sytuując jedno wybrane słowo w klauzuli, Miłosz nie tylko rozwiązywał problem rymu, czyli zagadnienie z zakresu czysto formalnej koherencji sekstyny, wymagającej wygłosowego współbrzmienia między wersem pierwszym a trzecim, drugim a czwartym, piątym a szóstym. Rozwiązywał także problem z zakresu symboliczno-ideowej koherencji strofy (sekstyna winna być wszak pewną myślową całością). W pierwszej z analizowanych zwrotek

\footnotetext{
${ }^{20} \mathrm{~W}$ języku critique génétique taki zapis określa się mianem transcription diplomatique; polski przekład podręcznika Biasiego proponuje pojęcie „transliteracja dyplomatyczna”. Marek Troszyński dla nazwania tego samego zabiegu używa jednak inaczej „ulepionego” terminu, chyba istotnie bardziej funkcjonalnego i etymologicznie umotywowanego: „transliteracja topograficzna”. Zob. Marek Troszyński, Alchemia rękopisu. „Samuel Zborowski” Juliusza Słowackiego (Warszawa: Wydawnictwo IBL, 2017), 37-43.
} 
- Ani ja wierzę w duszę nieśmiertelną

Ani nagrody szukam dla zasługi

odejmą

słowo „odejmą" nie było wcale najbardziej oczywistym odpowiednikiem brzmieniowym dla wyrazu „nieśmiertelną", właściwie mamy tu do czynienia $z$ asonansem (przy zasadniczo dominujących w tym utworze rymach dokładnych). Natomiast wyraźnie semantyka tego czasownika wiąże się z tym, co jest treścią wersu drugiego, rzec można, treść tę rozwija, wzmacnia: wers drugi mówi o rezygnacji ze zdobywania i zyskiwania („nie szukam nagrody” = nad to co mam, nic więcej nie chcę posiąść), klauzula wersu trzeciego mówi już o utracie („odejmą” = stracę to, co miałem). Innymi słowy, wprowadzenie do rodzącego się wiersza słowa „odejmą” jest podwójnie funkcjonalne: nawiązuje relację brzmieniową między wersem trzecim a pierwszym oraz „ustawia” wers trzeci jako znaczeniową amplifikację wersu drugiego. Podobnie dzieje się tutaj:

Jeżeli zechce, znowu mnie postawi

Nie mnie dochodzić u jakich płomieni

przetrawi

Słowo „przetrawi” jest niewątpliwie silnym, pełnym rymem dla „postawi”, ale też semantycznie koresponduje z „płomieniami” (ogień, który trawi, oczyszczenie). W obu wypadkach możemy więc obserwować podwójną kontrolę poety-rymotwórcy nad rodzącym się tekstem: Miłosz równocześnie domyka rymową strukturę wiersza in statu nascendi i ustawia stelaż jego semantycznej konstrukcji. A wszystko to czyni jedną, nieomylną kreską, od pierwszego dotknięcia kartki.

Dlatego słusznie się mówi, że dyktuje poezję dajmonion,

choć przesadza się utrzymując, że jest na pewno aniołem ${ }^{21}$.

Przesadzilibyśmy również, twierdząc, że rymy z piątej i szóstej sekstyny Rozmów na Wielkanoc 1620 zostały podyktowane przez daimoniona angelicznej, infernalnej czy jakiej bądź innej proweniencji. Obecność „jaśniejszych doodles” zdradza, że nawet w fazie pierwszej, czyli w trakcie rymowania i przeskakiwania między klauzulami, Miłosz nie tylko zapisywał wyrazy, lecz także coś gryzmolił na marginesach - a więc kontakt z kartką nie sprowadzał się do błyskawicznej notacji, do „stenografowania natchnienia”. Niemniej jednak proces „rymotwórczy” jawi się tu jako szybki, czaso- i energooszczędny, ekonomiczny. A w każdym razie relatywnie ekonomiczny - co, jak mniemam, za chwilę stanie się uderzająco jasne.

Mając w pamięci omówioną wyżej sekwencję z brulionowej historii wiersza Rozmowy na Wielkanoc 1620 roku, spójrzmy na ilustrację nr 2. Przedstawia ona wygląd pierwszej brulionowej karty, na której Miłosz rozpoczął - czy próbował rozpocząć - pisanie wiersza Na ścięcie damy $d w o r u^{22}$.

\footnotetext{
${ }^{21}$ Czesław Miłosz, Wiersze, t. 3 (Kraków: Znak, 2003), 78.

${ }^{22}$ Także w przypadku tego wiersza dokumentacja brulionowa znajduje się w Beinecke Library, pod identyczną sygnaturą, co bruliony Rozmów na Wielkanoc 1620 roku.
} 
praktyki | Mateusz Antoniuk, Poetyka, genetyka, praca. (O sztuce rymotwórczej)

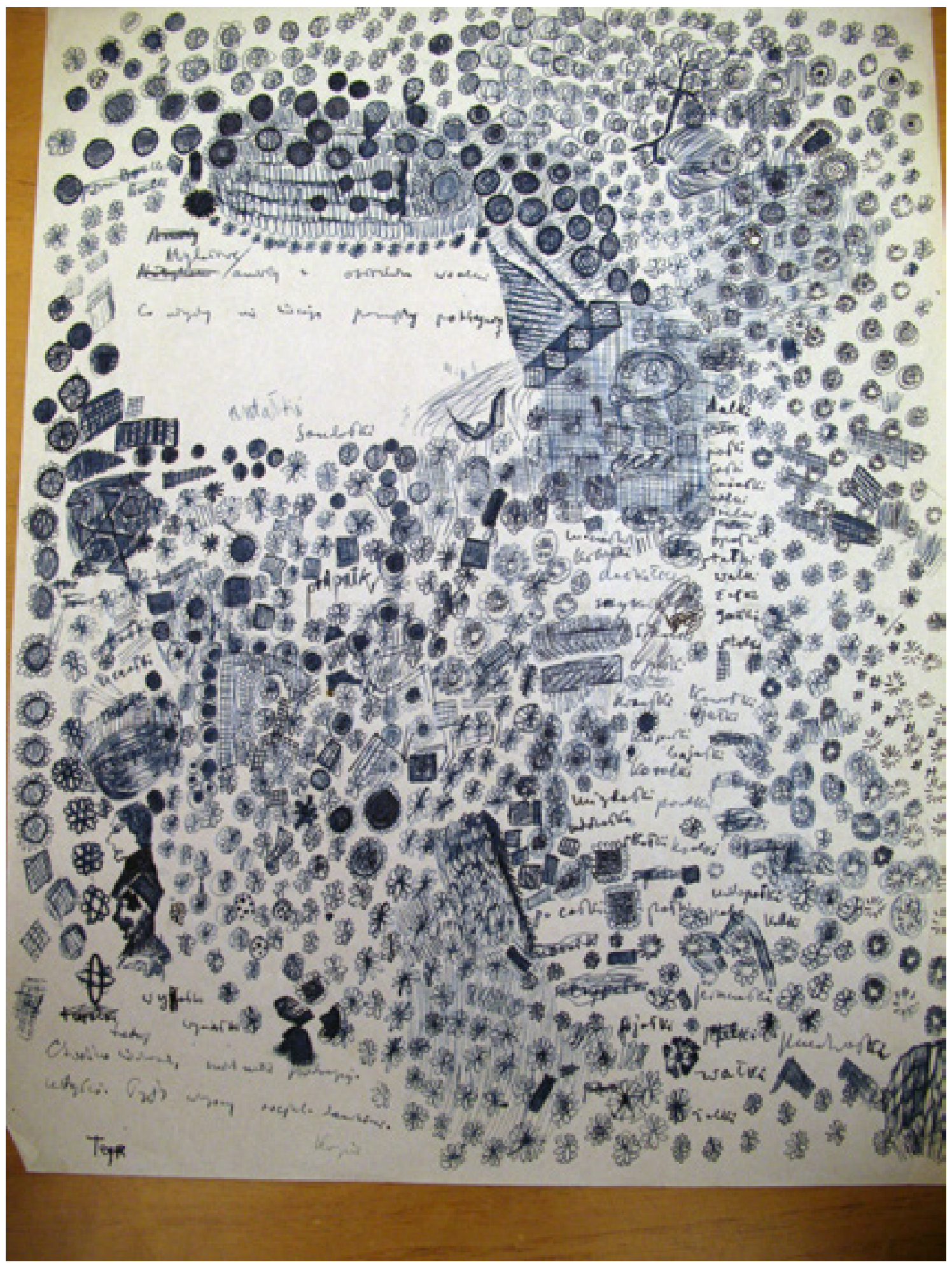

Ilustracja 2.: Brulion wiersza „Na ścięcie damy dworu” (pierwsza karta, początek pracy nad tekstem), Beinecke Rare Book and Manuscript Library, Yale University 
Niezwykły to obraz! Jeśli trzecia brulionowa karta Rozmów na Wielkanoc 1620 roku miała marginesy częściowo zapełnione rysunkami, tutaj proporcje ulegają odwróceniu: rysunki wypełniają niemal całą powierzchnię karty. Oprócz znanych nam już „kwiatków” oraz figur dają się też tu dostrzec dwa ludzkie profile, jeden (chyba) męski, drugi żeński. W tym wizualnie zdominowanym przez rysunki polu kartki sam zapis wyrazów jest jakby zamknięty w wąskim prześwicie. Trzeba „wpatrzyć” się w graficzno-literową kompozycję, zrozumieć, to, co ma nam ona do przekazania czy opowiedzenia - wówczas zaczyna się wyłaniać zarys genetycznej historii.

Spróbuję ją teraz opowiedzieć. Spróbuję odtworzyć - krok po kroku, możliwie dokładnie, choć, mam nadzieję, bez nadmiernej pedanterii - kolejność działań i zdarzeń, które stopniowo zmieniały białą kartę, na którą patrzył Miłosz, w tę plastyczną kompozycję, którą można dziś oglądać w czytelni Beinecke Library i którą przedstawia ilustracja nr 2.

A więc - było tak (a przynajmniej tak to sobie wyobrażam)... Na pustej karcie Miłosz zapisuje pierwszy wyraz:

Anioły

Spójrzmy na ilustrację 2, przyjrzyjmy się słowu „Anioły”, zwróćmy uwagę na jego przestrzenne usytuowanie. Czy na pewno poeta zaczął od zapisania tego wyrazu? Stosunkowo niskie położenie słowa, znaczna odległość pomiędzy nim a górną krawędzią kartki może nasuwać podejrzenie, że kontakt pióra z papierem zaczął się nie od zapisu „Anioły”, ale od znajdujących się nad nim rysunków (bo dlaczego poeta miałby zacząć inskrypcję tak „nisko”?). Jeśli jednak obejrzymy wiele brulionów Miłoszowych wierszy (zwłaszcza tych z okresu zbliżonego do Na ścięcie damy dworu), stwierdzimy, że również na tych rękopisach, w których doodles nie pojawiają się ponad pierwszą linią zapisywanego tekstu (czyli tam, gdzie pierwsze słowo mogło być pozycjonowane znacznie wyżej), Miłosz zachowuje wyraźnie zwiększone „światło” między inicjalnym wersem a górnym marginesem. Taki był po prostu jego sposób gospodarowania przestrzenią kartki, jego usus scribendi $i^{23}$.

Zatem - wracam do mojej opowieści. Na początku zapisał Miłosz - jak to patetycznie brzmi!, cóż poradzić, przez język krytyki genetycznej prześwitują zarysy archetypicznej, wielkiej opowieści o Genezie - a więc: Miłosz zapisał na początku wyraz „Anioły”. Przekreślił go następnie, postanowił zacząć swój wiersz inaczej: nie od rzeczownika, lecz od przydanego mu epitetu. Zapis na karcie wygląda „teraz” (słowo „teraz” jest oczywiście czysto retorycznym chwytem, symulującym nasze wniknięcie w proces pisania i jego czas) następująco:

Anioly

Nietykalne anioły z obłokiem woalki,

\footnotetext{
${ }^{23}$ Pojęcie usus scribendi, obejmujące, prócz autorskich przyzwyczajeń w zakresie przestrzennego rozmieszczania zapisu na kartce, także preferencje w zakresie nośników zapisu, narzędzi do pisania etc., wprowadzam za następującymi opracowaniami: Daniel Ferrer, „The Open Space of the Draft Page: James Joyce and Modern Manuscripts”, 256; Wim Van Mierlo, „The Archaeology of the Manuscript: Towards Modern Palaeography”, w: The Boundaries of the Literary Archive: Reclamation and Representation, red. Carrie Smith i Lisa Stead (Farnham: Ashgate Publishing, 2013), 17.
} 
Utwór ma więc swój inicjalny wers. W tym inicjalnym wersie Miłosz zmienił rychło epitet-pierwsze słowo, po czym dopisał wers drugi. Albo odwrotnie: Miłosz dopisał wers drugi, następnie wrócił do pierwszego, by zmienić otwierający epitet. Tak czy inaczej, na karcie - przed chwilą całkiem pustej, a teraz już będącej nośnikiem tekstu in statu nascendi - widnieje taka oto inskrypcja, taki oto ślad procesu tworzenia (ślad jeszcze „ciepły”, „świeży”):

Anioły

$$
\text { Migdałowe }
$$

Nietykalne anioły z obłokiem woalki,

Co nigdy nie kucają pomiędzy pokrzywą

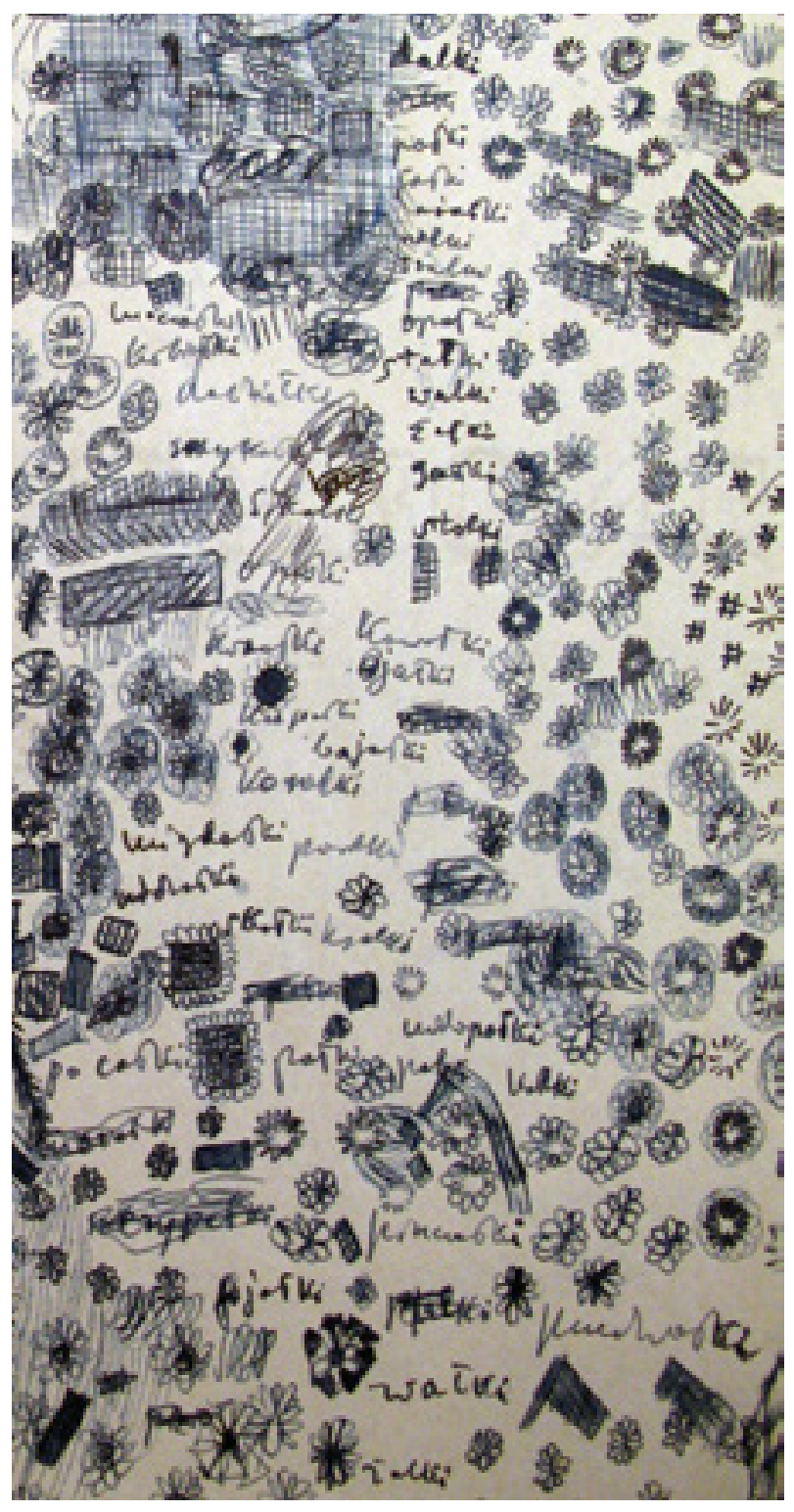

Ilustracja 3.: Brulion wiersza „Na ścięcie damy dworu” (pierwsza karta, fragment w powiększeniu), Beinecke Rare Book and Manuscript Library, Yale University
Teraz Miłosz powinien uruchomić trzeci wers, tak jak dwa pierwsze wersy - trzynastozgłoskowy. Albo - dlaczego nie? teraz Miłosz powinien „przeskoczyć” do klauzuli trzeciego wersu, zostawiając „na później” jego nagłos oraz wypełnienie, i „zrobić” pierwszy rym wiersza. Pamiętamy, jak skuteczna była ta rymotwórcza metoda w przypadku Rozmów... Ale każdy wiersz ma inną historię. Każde rymowanie ma inną dynamikę.

Spójrzmy na ilustrację numer 3, przedstawiającą w powiększeniu ten fragment rękopisu, w którym między „kwiatkami” pojawiają się pojedyncze słowa: „lalki”, "gałki”, „pałki”, „miałki”, , szalmi”, „opałki”, ,walki”, „kobiałki”, „kawałki”, „koralki”, „migdałki”, „bajałki”, „skałki”, „niedopałki”, „kalki”, „piszczałki”, „wałki”, „antałki”, „sandałki”, „podpałki”. Jedno łączy te wszystkie wyrazy - są one mniej lub bardziej dokładnymi rymami do „woalki”. Wiele wskazuje na to, że poeta faktycznie postanowił zadziałać wedle znanej nam już strategii tekstotwórczej i przystąpił do ustalenia klauzuli kolejnego wersu, do zrymowania pierwszego rymu. Wtedy jednak nastąpiło coś całkowicie odmiennego w swej dynamice - „zawieszenie się" rymującego umysłu, który zamiast znaleźć rozwiązanie problemu, zaczął w galopującym tempie multiplikować jego alternatywne rozwiązania. 
Jaki wniosek wysnuć można z faktu, iż słowa rymujące się z wyrazem „woalki” są „rozsypane” czy „wciśnięte” między niezliczone mikrorysunki? O funkcji doodles w procesie tekstotwórczym Miłosza już pisano, na różne sposoby i inspirująco: Bożena Shallcross Miłoszowe „rysopisanie” interpretowała za pomocą teoretycznie wyrafinowanego (a równocześnie „poetyckiego”) dyskursu o piśmie, rysunku, wizualności i widmowej obecności; Karina Jarzyńska doodles autora Światła dziennego interpretowała jako specyficzny przejaw prywatnego „ćwiczenia duchowego”, praktyki skryptualnej, psychofizycznej (angażującej ciało i umysł). Pierwsza komentatorka sugerowała, że mikrorysowanie mogło mieć funkcję regeneratywną („Wizualne notacje [...] mają wzmocnić słabnącą wolę, odnowić twórczą energię"24), druga skłonna była mówić o doodles jako o czynności służącej osiągnięciu „koncentracji” oraz ćwiczeniu się poety w „uważności”25. Ciekawe to myśli i mogę z ich pomocą pomyśleć o tym, konkretnym brulionie Miłosza (do którego akurat ani jedna, ani druga badaczka się nie odnosiła). Mogę zatem powiedzieć, że rysujący rymotwórca odpoczywa, przerywa pracę, by zregenerować swoją, wyczerpującą się w kolejnych próbach, rymotwórczą energię; albo, przeciwnie, mogę sobie wyobrażać, że rysując, pracuje ze szczególną intensywnością, skupiając swą uwagę na brzmieniu i znaczeniu idealnego słowa, korespondującego brzmieniowo z wyrazem ,woalki”.

Mógłbym też powiedzieć nieco ostrożniej, z większą asekuracją, nie traktując rękopisu jako wykresu aktywności tekstotwórczego umysłu, nazbyt wiele nie przesądzając, mniej odgadując: uderzająca hipertrofia doodles to wizualny wykładnik trudu i czasu związanego z wytwarzaniem „częściowej lub całkowitej zgodności brzmienia zakończeń wyrazów zajmujących określoną pozycję w wersie". Wygląda na to, że poeta - to chyba najlepsze określenie - ślęczy nad kartką, wpatruje się w nią i mozolnie, z trudem, „wydusza” z siebie (z pamięci, ze słownika, z języka) kolejne wyrazy. Ale żaden $\mathrm{z}$ nich nie okazuje się - w odczuciu autora - tym, który może domknąć brzmieniową i semantyczną strukturę. Czy rysunki pojawiają się w chwilach, gdy „rymotwórca” szczególnie intensywnie zastanawia się nad rymem idealnym, czy wówczas, gdy intensywność ta spada, a umysł poety przechodzi „w tryb spoczynku” - nigdy się tego nie dowiemy. Ale tak czy inaczej niepohamowany przyrost rysunków - we wszystkich kierunkach, na całej przestrzeni karty - jest znakiem, jest graficznym wykładnikiem przedłużającego się stanu oczekiwania na słowo domykające trzeci wers, wyrazem niemożności zrymowania rymu.

Znamienne, że pomiędzy „kwiatkami” - prócz wyrazów już przeze mnie odczytanych i wymienionych - można wyczytać i takie zapisy: „stałki”, „żałki”, „moczałki” [?], „jajki”, „kralki”, „uczałki”. Jeśli poprawnie odcyfrowuję i jeśli nie mści się na mnie brak kompetencji w zakresie dawnych form regionalnych polszczyzny ${ }^{26}$, nie są to chyba wyrazy, lecz po prostu nic nie znaczące grupy sylabowe, wypisywane w nadziei, że któraś z nich wywoła - skąd? z niepamięci? - upragnione słowo. Bezskutecznie (jeśli przez skutek rozumieć będziemy wynalezienie rozwiązania optymalnego, każącego natychmiast przerwać proces poszukiwań).

Nie wiem, dlaczego od czasu do czasu piszę rymowane wiersze, trudno mi na to pytanie odpowiedzieć. Takie mam natchnienie - co zrobić. O tyle nie lubię pisania takich rymowanych wierszy, że jak

\footnotetext{
${ }^{24}$ Bożena Shallcross, „Poeta i sygnatury”, Teksty Drugie, nr 5 (2011): 60.

${ }^{25}$ Karina Jarzyńska, Literatura jako ćwiczenie duchowe. Dzieło Czesława Miłosza w perspektywie postsekularnej

(Kraków: Towarzystwo Autorów i Wydawców Prac Naukowych „Universitas”, 2018), 270-272.

${ }^{26}$ Co by nie dziwiło - u autora Elegii na kłopoty z polszczyznq...
} 
człowiek zacznie, to już musi dalej znaleźć rymy. To znaczy pierwsza linia jest dana, a potem musisz, bracie, dalej pisać, już nie ma rady. Chcesz, nie chcesz, płaczesz, musisz siedzieć i skończyćc7

- tak o doświadczeniu pisania rymowanego wiersza opowiadał Miłosz Renacie Gorczyńskiej. Wydaje się, że pierwsza brulionowa karta utworu Na ścięcie damy dworu jest znakomitą wizualizacją tego, o czym poeta mówi w ostatnim zdaniu. Rym staje się tu - potrzaskiem.

Jak dokonało się „wyjście z potrzasku”? Po prostu - przez wybór jednego ze słów już zapisanych „między kwiatkami”. „Lalki” - Miłosz postawił ostatecznie na ten wyraz. Ciekawą kwestią jest jego położenie na karcie. Spójrzmy raz jeszcze na ilustrację nr 3. Słowo „lalki” widnieje stosunkowo blisko prześwitu z zapisanymi dwiema inicjalnymi liniami, co ważne: na początku sekwencji wyrazów, ujętej w formę słupka (zakładam, że Miłosz słupek ten zapisywał w porządku zgodnym z piśmienniczymi przyzwyczajeniami oka i ręki, czyli od góry do dołu). Można zatem powiedzieć: Miłosz w długiej pisarskiej sesji przeszukiwał imaginatywny słownik, odrzucając kolejne, znajdywane w nim opcje, opcji tych rozpatrzył kilkadziesiąt, by ostatecznie wrócić do słowa, które... rozpatrywał jako pierwsze. Nic jednak w pierwszym brulionie nie wskazuje jeszcze na dokonanie rozstrzygnięcia: żaden graficzny znak w postaci, na przykład, zakreślenia czy podkreślenia wybranego wyrazu. Pierwszy ślad podjętej decyzji widoczny jest dopiero w brulionie drugim:

Migdałowe anioły z obłokiem woalki

co nigdy nie kucają pomiędzy pokrzywą

I Ciało mają bez dziurek mają, gładkie jak u lalki

„Woalki” - „lalki”. Poetyka statyczna, poetyka wytworu, powie, że jest to: rym okalający (ze względu na jego położenie w strukturze strofy), gramatyczny pełny, końcówkowy (pod względem formy gramatycznej), paroksytoniczny (pod względem prozodyjnym), dokładny (pod względem fonetycznym). Poetyka genetyczna, poetyka wytwarzania, doda: rym hipertrudny do skonstruowania, czego świadectwem pozostaje jedna, gęsto zarysowana i zapisana karta...

Nie będę już opowiadał dalszego ciągu brulionowej historii wiersza Na ścięcie damy dworu. Choć do opowiedzenia - zostało jeszcze wiele. Format publikacji artykułowej skłania do zwięzłości i operowania zasadą kadru, przykładowego wycinka; być może historię tę przedstawię kiedyś dokładniej w obszerniejszej pracy ${ }^{28}$. Teraz dopowiem tylko, że opisana wyżej sytuacja

\footnotetext{
${ }^{27}$ Czesław Miłosz, Podróżny świata, rozmowy z Renatą Gorczyńską (Kraków: Wydawnictwo Literackie, 2002), 266. Uwaga Miłosza o poecie płaczącym nad niedającym się znaleźć - czy wynaleźć - rymem brzmi jak, niekoniecznie zamierzona, reminiscencja ze słynnej metaoktawy (oktawy o oktawie) Juliusza Słowackiego, gdzie, jak pamiętamy, trudność z ustaleniem „trzeciego rymu”, wymaganego przez regułę strofiki, także wywołuje łzy „wieszcza piszącego poemat oktawą”...

${ }^{28}$ Odnotowuję jedynie: pomijam w mojej opowieści także ten, niewątpliwie istotny, fakt, że na pierwszej stronie brulionu wiersza $\mathrm{Na}$ ścięcie damy dworu widnieje też inna jeszcze inskrypcja. Otóż w lewym dolnym rogu znajduje się trudno czytelny zapis dwóch wersów. Odczytuję go, nie bez wahań, następująco: „Chodźcie [...] niech mnie podrapią [?]/ Utyłeś. Tyją wszyscy socjal-demokraci”. Ewidentnie zapis ten nie wiąże się z główną „sprawą” kartki, czyli szukaniem pierwszego rymu wiersza - wniosek z tego, że kartka była również sceną (czy narzędziem) zmagań $z$ innym jeszcze problemem, $z$ innym miejscem rodzącego się tekstu. Być może - ale to jedynie hipoteza, chyba nieweryfikowalna - jest to zapis poszukiwania możliwej, antycypowanej puenty dopiero co rozpoczętego wiersza. Choć jest i taka możliwość, że mamy tu do czynienia z zapisem dygresyjnym, z rodzącym się na marginesie wierszem innym, osobnym. W każdym razie słowa takie (lub podobne) nie pojawiają się w wersji opublikowanej Na ścięcie damy $d w o r u$, nie przypominam ich też sobie jako składnika jakiegokolwiek wydrukowanego wiersza Czesława Miłosza.
} 
„zapętlenia” wokół jednego rymu jeszcze kilkukrotnie powtórzyła się w toku pracy nad tym utworem. Aby doprowadzić liryk do, znanej z druku, ujętej w dystych, puenty:

Dziś ja wielki, największy z całego powiatu

Ogłosić mogę wyrok. Służba. Dać ją katu.

Miłosz potrzebował jeszcze czterech kart brulionowych. „Po drodze” zatrzymało go między innymi wyszukiwanie rymów do słów „pokrzywą" i „wioski”. Kłopot z rymem powtarzał się, pierwsze „zablokowanie” okazało się jakby odnawialnym paradygmatem tego konkretnego procesu tekstotwórczego - choć trzeba wyraźnie zaznaczyć, że już żadne z późniejszych „zawieszeń" nie było tak długotrwałe, intensywne, dramatyczne. Tylko na pierwszej karcie brulionowej - ściślej: po zapisaniu dwóch pierwszych wersów, przed zapisaniem wersu trzeciego - doszło nie tyle do spowolnienia, nie tyle do wytracenia tempa tekstotwórczej akcji, ile raczej do jej zakleszczenia. Brulionowa karta, przedstawiona na ilustracji numer 2, to perfekcyjna wizualizacja niemożności.

Dwie wybrane sekwencje dwóch akcji tekstotwórczych pozwalają nam zobaczyć, jak różnie przebiegać może sama czynność rymowania. I jak rozmaicie może się ona wiązać z innymi czynnościami tekstotwórczymi. W wypadku piątej i szóstej strofy Rozmów na Wielkanoc w roku 1620 rymowanie jest główną czynnością formotwórczą: rym prowadzi niejako rękę poety, rymowanie napędza przyrost tekstu. Strukturę rymową porównać tu można do stelażu, do szybko wznoszonego rusztowania, które determinuje kształt przyszłej tekstowej - brzmieniowej i znaczeniowej - konstrukcji. W wypadku początkowych partii wiersza $\mathrm{Na}$ ścięcie damy dworu dzieje się dokładnie odwrotnie: rymowanie okazuje się problemem, który - długo nierozwiązany, przedłużający się - blokuje proces przyrastania tekstu. W pierwszym wypadku rym jest katalizatorem procesu tekstotwórczego, w drugim - jego spowalniaczem.

To wszystko można spuentować jeszcze prościej, krócej. Dwa odcinki mowy wiązanej, ten:

Lecz jako Bóg mnie postawił na ziemi, Jeżeli zechce, znowu mnie postawi.

Nie mnie dochodzić, u jakich płomieni, W jakich kuźnicach serce mi przetrawi

i ten

Migdałowe anioły z obłokiem woalki, Co nigdy nie kucają pomiędzy pokrzywą,

Ciało bez dziurek mają, gładkie jak u lalki

I nikt ich nie potrafi zaprosić na piwo.

w świetle poetyki genetycznej (poetyki wytwarzania) jawią się jako produkty dwóch, nieporównywalnych pod względem wkładu pracy, operacji tekstotwórczych. Tak jakby pracując nad pierwszym z cytowanych czterowersów, Miłosz kierował się tymi fragmentami Sztuki rymotwórczej, które chwalą łatwość i lekkość rymowania („Gdzie rym dużo kosztuje, nie będzie 
bez wady"), pracując zaś nad czterowersem drugim, słuchał raczej innego pouczenia z tego samego traktatu („Pośpieszaj, ale z wolna”) ${ }^{29}$.

\section{A więc: praca}

„Pojęcia z zakresu poetyki są zapisem poznawczego wysiłku, by zbadać i opisać pracę ludzkiego umysłu" - powiada Dorota Korwin-Piotrowska ${ }^{30}$. Twierdzę, że genetyczny modus operandi jest jednym z uprzywilejowanych, jednym ze szczególnie skutecznych trybów dostępu do „pracy ludzkiego umysłu", jaki może uzyskać poetyka czy też - by wreszcie pożegnać figurę personifikacji, chyba w tym artykule nadużytą - jaki może uzyskać badacz praktykujący poetykę (genologię, wersologię, stylistykę, naukę o kompozycji, narratologię...). Oczywiście, nie jest to dostęp ani pełny, ani pewny: procesy myślowe konkretnego człowieka w chwili pisania konkretnego tekstu nie dadzą się zrekonstruować na podstawie brulionu tak, jak, dajmy na to, przebieg pracy serca w ciągu określonego, krótkiego odcinka czasu daje się odtworzyć na podstawie wykresu, zwanego elektrokardiogramem.

Jeśli miałbym jakoś skonceptualizować nieoczywistą relację między brulionem tekstu (który możemy odnaleźć w archiwum) a tekstotwórczym umysłem (którego nie możemy dotknąć, wziąć do ręki), wahałbym się między dwoma pojęciowymi uchwytami. Z jednej strony byłoby to pojęcie (metafora?) śladu, tak ważne dla filozoficznej refleksji naszej współczesności, $\mathrm{z}$ drugiej pojęcie (metafora?) extended mind, wprowadzone do dyskursu humanistycznego pod koniec XX wieku przez Andy'ego Clarka i Davida Chalmersa ${ }^{31}$, następnie zaś, już w XXI wieku, skutecznie zoperacjonalizowane dla potrzeb krytyki genetycznej przez Dirka Van Hulle ${ }^{32}$.

Wybierając opcję pierwszą, mówiłbym: brulion (ze wszystkimi swoimi skreśleniami, dopiskami, z całą swoją materialnością) jest śladem mentalnych procesów odbywających się w umyśle autora. Śladem - a więc czymś nieuchronnie ułomnym, zwodniczym, resztkowym, nieprzechowującym pełni obecności tego, co odciska, co pozostawia ślad. Ale jednak (przynajmniej wedle niektórych, nie tych radykalnie krytycznych, filozofii śladu) poświadczającym o przemijającej i minionej realności ${ }^{33}$.

\footnotetext{
${ }^{29}$ Genetyczna poetyka rymu staje się faktem! W chwili, w której dokonuję ostatniej redakcji tego szkicu, do moich rąk trafia niezmiernie ciekawy szkic Tadeusza Budrewicza, poświęcony pracy nad rymem podejmowanej przez Adama Asnyka. Budrewicz dysponował materiałem, który inaczej ustawia ogląd zagadnienia: przedmiotem uwagi nie jest tu brulion utworu, ale notes służący Asnykowi do zapisywania rymujących się wyrazów, gotowych później do użycia w wierszach. Mamy tu więc (najprawdopodobniej) do czynienia z pracą rymotwórczą niezwiązaną jeszcze z konkretnym utworem literackim, niejako uprzednią wobec właściwych procesów tekstotwórczych. Sposób, w jaki Budrewicz problematyzuje to zjawisko, jest znakomity - obserwacje z zakresu poetyki historycznej są powiązane między innymi ze współczesną Asnykowi refleksją teoretyczną na temat zjawiska rymu. Zob. Tadeusz Budrewicz, „Asnyka notes z rymami”, w Przed-tekstowy świat. Z literackich archiwów XIX i XX wieku, red. Marzena Woźniak-Łabieniec (Łódź: Wydawnictwo Uniwersytetu Łódzkiego, 2020), 31-50. ${ }^{30}$ Zob. przyp. 8.

${ }^{31}$ Zob. Andy Clark, David Chalmers, „The Extended Mind”, Analysis, nr 58 (1998): 10-23.

${ }^{32}$ Zob. Dirk Van Hulle, Modern Manuscripts. The Extended Mind and Creative Undoing from Darwin to Beckett and Beyond (London, New Delhi, New York, Sydney: Bloomsbury Publishing, 2014).

${ }^{33}$ Por. Andrzej Zawadzki, Obraz i ślad (Kraków: Wydawnictwo Uniwersytetu Jagiellońskiego, 2014), 7: „[...] podstawowe pytanie ontologiczne, pytanie dotyczace śladu: czy jest on «żywym» znakiem i świadectwem obecności tego, kto, czy tego, co ślad pozostawiło, czy też przeciwnie - martwym, mechanicznym odciskiem, w którym wszelka obecność ginie bądź okazuje się jedynie wtórnym efektem działania śladu. To drugie stanowisko najlepiej oddaje myśl Jacques'a Derridy, stanowiska pierwszego broni natomiast między innymi Barbara Skarga, której rozważania o śladzie mają, na polskim gruncie, założycielski charakter".
} 
Wybierając opcję drugą, podążałbym torem Dirka Van Hulle i twierdził tak mniej więcej: brulion nie jest tylko biernym (i niedoskonałym) odbiciem procesów kreacyjnych, odbywających się poza nim, mających swe ulokowanie w, nieco zmityzowanym, wnętrzu umysłu (któremu nadawano i któremu nadaje się te wszystkie niezliczone imiona i miana: świadomość, podświadomość, wyobraźnia...). Brulion jest także - interaktywną częścią tekstotwórczej maszynerii. Autor „myśli w głowie”, ale równocześnie patrzy na zapis swoich myśli „na kartce”, to, co widzi „na kartce”, stymuluje (a może czasem blokuje) pracę „myśli w głowie”, wciąż szukającą wyrazu we (wciąż percypowanym) zapisie "na kartce" - innymi słowy tekst rodzi się tyleż w „głowie”, co „na kartce”. Czy może lepiej jeszcze: nie rodzi się ani „w głowie”, ani „na kartce”, lecz w „głowie-i-na kartce” (,i” jak „interakcja”).

Bruliony omawiane w tym artykule - ten przedstawiony na ilustracji 1, na którym „widać", że Miłosz zaczynał pisanie wersów od ich wygłosów, a dopiero później wypełniał puste miejsca, i ten przedstawiony na ilustracji 2, który ujawnia kryzys rymotwórczej, i w konsekwencji tekstotwórczej, inwencji - możemy zatem traktować dwojako: albo jako nośniki słabego śladu kreatywnej aktywności umysłu, albo jako nieczynny już, wyłączony, lecz niegdyś aktywny, „uzewnętrzniony umysł”. Którąkolwiek retorykę i logikę wybierzemy, jedno pozostaje niezmienne - właśnie te kartki pozwalają badaczowi „rymu Miłosza” percypować ów rym nie jako wytwór, ale jako wytwarzanie. Inaczej mówiąc: sprawiają, że poetyka wraca poniekąd do swego źródłosłowu i znów oznacza namysł nad tworzeniem ${ }^{34}$.

Powiem to jeszcze raz: stawką, o którą może grać „poetyka genetyką podszyta”, jest właśnie pełniejsze, skuteczniejsze uchwycenie za pomocą poetologicznych pojęć i procedur faktyczności pracy, niejako ukrytej czy zakodowanej w estetycznych strukturach dzieła. Pracy - jak powiadają kognitywiści - ucieleśnionego umysłu. Koniec końców chciałbym jednak oddalić się nieco od tego kognitywistycznego słownika, a zarazem bardziej uogólnić kwestię „pracy”. Owszem, praca, którą odsłania poetyka genetyczna, jest pracą psychofizycznego podmiotu, zwanego autorem ${ }^{35}$, ale da się ją też skonceptualizować jako pracę języka, który w brulionach właśnie męczy się i wysila, by ostatecznie „wyjęzyczyć” jakiś sens, czy też jako pracę konwencji literackich, zaprzężonych do kieratu tekstotwórczych (i sensotwórczych) młynów.

Wydaje mi się, że takie właśnie przekierowanie poetyki - w kierunku pracy, rozumianej jako praca wytwarzania tekstu, ale też szerzej, jako przejaw aktywnego, pożytecznego i twórczego modusu bycia w świecie - przesuwa tę poetykę (tylekroć już w ostatnich latach odsyłaną

\footnotetext{
${ }^{34}$ Skądinąd nawiązywanie do etymologii pojęcia „poetyka”, niejako noszącego w sobie pamięć greckiego czasownika poiein („wytwarzać”), należy do toposów metapoetologicznego dyskursu. Przypominała ten „czynnościowy” rodowód pojęcia m.in. Teresa Kostkiewiczowa w pracy „Poetyka dawniej i dziś”, Tematy i Konteksty, nr 3 (2013), 35-44, przypominał go (pośrednio, odwołując się do szkicu Kostkiewiczowej) Tomasz Mizerkiewicz („Nowe sytuacje poetyki”); powoływał się nań, dając temu wyraz już w tytule artykułu, Piotr Sobolczyk, dyskutując o projekcie „poetyki kognitywnej”, zob. „Kognitywna vs. Kognicyjna? Poetyka vs Poietyka?”, Teksty Drugie, nr 4 (2010), 88-100.

${ }^{35}$ Choć warto tu jeszcze dodać, że krytyka genetyczna nie jest skupiona wyłącznie na instancji autora, postrzeganego jako suweren procesu twórczego. Genetyka dostrzega problem „wielo-sprawczości” tekstu, sprawczości rozdzielonej (w różnym, rzecz jasna, a nie równym stopniu) między wieloma agensami, włączającymi się, na różnych etapach procesu twórczego, w pracę kreacji. Znakomitym przykładem takiej konceptualizacji jest dostępny w języku polskim artykuł: Nicolas Donin, Daniel Ferrer, „Autor(zy) i aktorzy genezy", tłum. Dorota Jarząbek-Wasyl, Wielogłos 39, nr 1 (2019), 37-63.
} 
do lamusa, ewentualnie spychaną do roli czysto służebnej) bliżej centrum (ostrożniej: jednego z możliwych centrów) współczesnej refleksji humanistycznej. Głośne pytanie Adrienne Rich „Does this poem work" 36 - pytanie, w którym czasownik "to work” nie oznacza tylko słowa „działać”, lecz zawiera w sobie rys „pracować” - rozlicza przecież wiersz z „pracowitości”, to jest ze zdolności działania. Działania, przede wszystkim, na odbiorcę (a poprzez niego - na świat, jakkolwiek patetycznie może to wybrzmieć). Jeśli interesuje nas dziś „pracowitość tekstu”, naturalne staje się też uwzględnienie „pracowitości brulionu”. Czy też jeszcze inaczej: atrakcyjne staje się budowanie interdyscyplinarnych opowieści z pogranicza poetyki, genetyki, historii idei czy antropologii kultury, przedstawiających historie „pracy nad tekstem” (czyli pracy wykonywanej przez tekstotwórczy umysł ucieleśniony), historie „pracy tekstu” (czyli pracy polegającej na „przepracowywaniu” świadomości nas-czytelników przez teksty) i historie „pracy tekstem” (czyli pracy wykonywanej przez tych pisarzy i czytelników, którzy swoimi tekstotwórczymi i hermeneutycznymi aktami przetwarzają świat społecznych interakcji) ${ }^{37}$. Ale to już temat szerszy, temat - na inny (i bardzo pracowity) szkic...

${ }^{36}$ Adrienne Rich, Poetry and Commitment. An Essay (London, New York: W.W. Norton \& Company, 2007).

${ }^{37}$ Nawiązuje do terminów i rozważań przedstawionych przez Ryszarda Nycza w książce Kultura jako czasownik. Sondowanie nowej humanistyki (Warszawa: Wydawnictwo IBL, 2017), 174-175.

\section{Bibliografia}

Antoniuk, Mateusz. „«Bebeszenie (się) dramatu», albo «jakże to Herbert pisywał...». O powstawaniu dramatu sokratejskiego". W Archiwa i bruliony pisarzy. Odkrywanie. Zredagowane przez Maria Prussak, Paweł Bem, Łukasz Cybulski, 217-255. Warszawa: IBL PAN, 2017.

---. „Między intencją i realizacją. Powstawanie dramatu «Baśń zimowa»". W Pracownia Herberta. Studia nad procesem tekstotwórczym. Zredagowane przez Mateusz Antoniuk, 359370. Kraków: Wydawnictwo Uniwersytetu Jagiellońskiego, 2017.

---. „ «Miłoszologia» i «krytyka genetyczna» (rekonesans)". Świat i Słowo 25, nr 2 (2015), 112-133.

---. „Przybranie formy z dawna wyglądanej (dosięganej / obiecanej / wysnowanej...). Brulion Czesława Miłosza - próba lektury”. Teksty Drugie, nr 3 (2014), 29-48.

---. Stowo raz obudzone. Poezja Czesława Miłosza - próby czytania. Kraków: Księgarnia Akademicka, 2015.
Balbus, Stanisław. „Granice poetyki i kompetencje teorii literatury". W Poetyka bez granic. Zredagowane przez Włodzimierz Bolecki, Wojciech Tomasik. Warszawa: Wydawnictwo IBL, 1995, 7-31.

---. Między stylami. Kraków: Towarzystwo Autorów i Wydawców Prac Naukowych „Universitas”, 1993.

Bem, Paweł. Dynamika wariantu. Miłosz tekstologicznie. Warszawa: Wydawnictwo IBL, 2017.

Biasi, Pierre-Marc de. Genetyka tekstów. Przetłumaczone przez Filip Kwiatek i Maria Prussak. Warszawa: Wydawnictwo IBL, 2015.

Bradford, Curits. Yeats at Work. New York: Ecco Press, 1978.

Budrewicz, Tadeusz. „Asnyka notes z rymami”. W Przed-tekstowy świat. Z literackich archiwów XIX i XX wieku. Zredagowane przez Marzena Woźniak-Łabieniec. Łódź: Wydawnictwo Uniwersytetu Łódzkiego, 2020. 
Burzyńska, Anna R. „«Pomysł w kształcie trójkąta», czyli «Trzy lekcje lustra»". W Pracownia Herberta. Studia nad procesem tekstotwórczym. Zredagowane przez Mateusz Antoniuk, 371-378. Kraków: Wydawnictwo Uniwersytetu Jagiellońskiego, 2017.

\section{---. „Praca na rzeczywistości. Ślady dokumentalności w procesie twórczym «Lalka»". W Pracownia Herberta. Studia nad procesem tekstotwórczym. Zredagowane przez Mateusz Antoniuk, 335-358. Kraków: Wydawnictwo Uniwersytetu Jagiellońskiego, 2017.}

Clark, Andy, Chalmers, David. „The Extended Mind”. Analysis, nr 58 (1998), 7-19.

Dawidowicz-Chymkowska, Olga. Przez kreślenie do kreacji. Analiza procesu twórczego, zapisanego $w$ brulionach dzieł literackich. Warszawa: Wydawnictwo IBL, 2007.

Debray Genette, Raymonde. Métamorphoses du récit. Paris: Seuil, 1988.

Dłuska, Maria. Studia z historii i teorii wersyfikacji polskiej. T. 1 i 2. Kraków: PAU, 1948-1950.

Dmochowski, Franciszek Ksawery. Sztuka rymotwórcza. Wrocław: Zakład Narodowy im. Ossolińskich, 1956.

Donin, Nicolas, Ferrer, Daniel. „Autor(zy) i aktorzy genezy”. Przetłumaczone przez Dorota Jarząbek-Wasyl. Wielogłos 39, nr 1 (2019), 37-63.

Ferrer, Daniel. „The Open Space of the Draft Page: James Joyce and Modern Manuscripts". W The Iconic Page in Manuscript, Print, and Digital Culture. Zredagowane przez George Bornstein i Theresa Tinkle, 249-68. Ann Arbor: University of Michigan Press, 1998.

Furmanik, Stanisław. „Rym”. W: Furmanik, Stanisław. Z zagadnień wersyfikacji polskiej. Warszawa: Państwowe Wydawnictwo Naukowe, 1956.

Głowiński, Michał, Okopień-Sławińska, Aleksandra, Sławiński, Janusz. Zarys teorii literatury. Warszawa: Państwowe Zakłady Wydawnictw Szkolnych, 1972.

Jakobson, Roman. „O lingwistycznej analizie rymu”. Prace Filologiczne XVIII (1963), 47-52.
Jarzyńska, Karina. Literatura jako ćwiczenie duchowe. Dzieło Czesława Miłosza w perspektywie postsekularnej. Kraków: Towarzystwo Autorów i Wydawców Prac Naukowych „Universitas”, 2018.

Korwin-Piotrowska, Dorota. Poetyka: Przewodnik po świecie tekstów. Kraków: Wydawnictwo Uniwersytetu Jagiellońskiego, 2011.

----. „Życie pośmiertne poetyki”. Tematy i Konteksty, nr 3 (2013), 20-34.

Kostkiewiczowa, Teresa. „Poetyka dawniej i dziś”. Tematy i Konteksty, nr 3 (2013), 35-44.

Kulawik, Adam, Miodońska-Brookes, Ewa, Tatara, Marian. Zarys poetyki. Warszawa: Państwowe Wydawnictwo Naukowe, 1972.

Mitosek, Zofia. „Morał i historia (transformacje sensu w genezie "Bram raju» Jerzego Andrzejewskiego". W Ecriture / Pisanie. Materiaty z konferencji polsko-francuskiej, Warszawa, październik 1992. Zredagowane przez Zofia Mitosek i Jakub Zdzisław Lichański, 41-49. Warszawa: Wydawnictwo DiG, 1995.

Mizerkiewicz, Tomasz. „Nowe sytuacje poetyki”. Forum Poetyki, lato 2015, http://fp.amu.edu. pl/lato-2015-20151/ (dostęp: 10.08.2020).

Mukařovsky, Jan. „O języku poetyckim”. W Praska szkoła strukturalna w latach 1926 1948. Wybór materiałów, 130-206. Warszawa: Państwowe Wydawnictwo Naukowe, 1966.

Nitsch, Kazimierz. „O nowych rymach”, "O rymach głębokich i niezupełnych", „Z historii polskich rymów”. W Nitsch, Kazimierz. Wybór pism polonistycznych. Wrocław: Zakład Narodowy im. Ossolińskich, 1954.

Nycz, Ryszard. Kultura jako czasownik. Sondowanie nowej humanistyki. Warszawa: Wydawnictwo IBL, 2017.

Pszczołowska, Lucylla. Rym. Wrocław: Zakład Narodowy im. Ossolińskich - Wydawnictwo Polskiej Akademii Nauk, 1972.

Rich, Adrienne. Poetry and Commitment. An Essay. London, New York: W.W. Norton \& Company, 2007. 
Shallcross, Bożena. „Poeta i sygnatury”, Teksty Drugie, nr 5 (2011), 53-61.

Siedlecki, Franciszek. Studia z metryki polskiej. Cz. 2. Problem transakcentacji w wierszu polskim. Wilno: z zasiłku Funduszu Kultury Narodowej, 1937.

Sobolczyk, Piotr. „Kognitywna vs. Kognicyjna? Poetyka vs Poietyka?", Teksty Drugie, nr 4 (2010), 88-100.

Tomaszewski, Boris W. „Przyczynek do historii rymu rosyjskiego”. W Rosyjska szkoła stylistyczna. Zredagowane przez Maria Renata Mayenowa i Zygmunt Saloni, 55-63. Warszawa: Państwowy Instytut Wydawniczy, 1970.

Troszyński, Marek. Alchemia rękopisu. „Samuel Zborowski” Juliusza Stowackiego. Warszawa: Wydawnictwo IBL, 2017.

Van Hulle, Dirk. Modern Manuscripts. The Extended Mind and Creative Undoing from Darwin to Beckett and Beyond. London, New Delhi, New York, Sydney: Bloomsbury Publishing, 2014.

Van Mierlo, Wim. „The Archaeology of the Manuscript: Towards Modern Palaeography". W The Boundaries of the Literary Archive: Reclamation and Representation. Zredagowane przez Carrie Smith i Lisa Stead, 15-29. Farnham: Ashgate Publishing, 2013.

Zawadzki, Andrzej. Obraz i ślad. Kraków: Wydawnictwo Uniwersytetu Jagiellońskiego, 2014. 


\title{
SŁOWA KLUCZOWE:
}

\author{
prac a \\ P O E T Y K A \\ $\boldsymbol{r} \boldsymbol{y} \boldsymbol{m}$
}

\section{ABSTRAKT:}

Artykuł jest próbą odpowiedzi na pytanie o to, jakie korzyści może zyskać poetyka, wchodząc w metodologiczną kooperację z krytyką genetyczną. Odpowiedź opiera się na definicji, sformułowanej przez Dorotę Korwin-Piotrowską, stwierdzającą, że „pojęcia z zakresu poetyki są zapisem poznawczego wysiłku, by zbadać i opisać pracę ludzkiego umysłu". W szkicu postawiona zostaje teza, wedle której szczególna (choć rzecz jasna ograniczona) możliwość poznawania „pracy ludzkiego umysłu” pojawia się wówczas, gdy poetyka - współpracując z krytyką genetyczną - zajmuje się nie tylko gotową postacią tekstu, lecz także tekstem in statu nascendi (zapisem procesu tekstotwórczego, jakim jest brulion). Twierdzenie to zostaje następnie zilustrowane za pomocą poglądowej analizy, łączącej opis poetologiczny z genetycznym, a poświęconej pracy nad rymem, wykonywanej przez Czesława Miłosza w trakcie pisania dwu wierszy: Rozmów na Wielkanoc 1620 roku i Na ścięcie damy dworu. W zakończeniu szkicu pojawiają się dalsze uwagi teoretyczne, między innymi odwołujące się do pojęcia extended mind oraz współczesnych, podmiotowych i czynnościowych koncepcji kultury. 
praktyki | Mateusz Antoniuk, Poetyka, genetyka, praca. (O sztuce rymotwórczej)

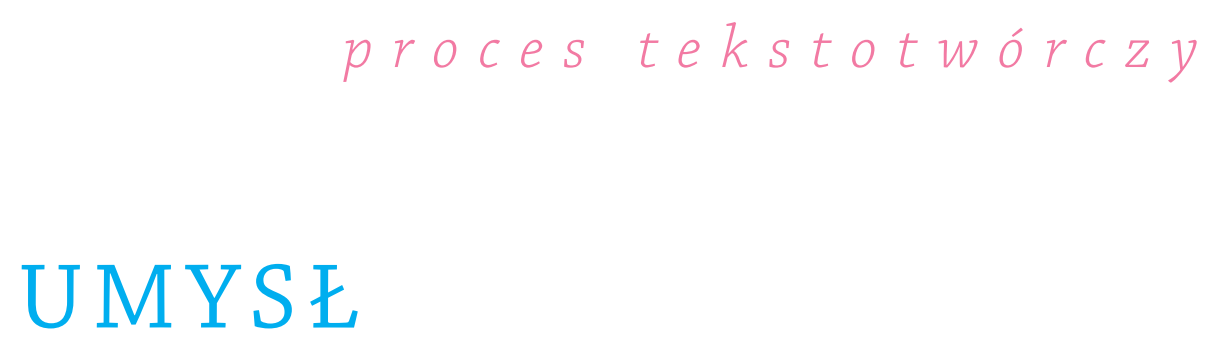

krytyka genetyczna

\section{NOTA O AUTORZE:}

Mateusz Antoniuk - dr hab., literaturoznawca, pracuje na Wydziale Polonistyki Uniwersytetu Jagiellońskiego, ostatnio opublikował książki: Pracownia Herberta. Studia nad procesem tekstotwórczym (współautorstwo, Kraków 2017) i Słowo raz obudzone. Poezja Czesława Miłosza: próby czytania (Kraków 2015). Szkice o tematyce literaturoznawczej publikował m.in. w „Tekstach Drugich”, „Przestrzeniach Teorii”, „Wielogłosie”, „Ruchu Literackim” oraz w „Textual Cultures”. Zainteresowania: literatura polska XX wieku, teoria i praktyka badań nad procesem twórczym. 